University of Wollongong

Research Online

Faculty of Engineering and Information

Faculty of Engineering and Information

Sciences - Papers: Part A

Sciences

January 2016

Performance evaluation of railway subballast stabilised with geocell based on pull-out testing

Mohammad Mahdi Biabani

University of Wollongong, mmb958@uowmail.edu.au

Ngoc Trung Ngo

University of Wollongong, trung@uow.edu.au

Buddhima Indraratna

University of Wollongong, indra@uow.edu.au

Follow this and additional works at: https://ro.uow.edu.au/eispapers

Research Online is the open access institutional repository for the University of Wollongong. For further information contact the UOW Library: research-pubs@uow.edu.au 


\title{
Performance evaluation of railway subballast stabilised with geocell based on pull-out testing
}

\begin{abstract}
A large-scale apparatus was designed and built at the University of Wollongong to evaluate the pull-out strength of rail subballast reinforced with geocells. A series of tests were carried out to investigate the pull-out resistance, mobilised tensile strength (ttensile) and passive strength (tpassive) of a subballastgeocell assembly under a given range of overburden pressure $(1 \mathrm{kPa}<\mathrm{q}<45 \mathrm{kPa})$. The interface was held in a vertical alignment to better simulate the interaction between subballast and geocell in accordance with routine track practices. The test results show that the geocell reinforcement provides a considerable degree of passive resistance, where the opening area $(\mathrm{OA})$ and lateral pressure (sn) over the geocell strip are found to be influential factors. A three-dimensional finite element simulation was also conducted. The numerical results show that the tensile strength mobilised in the geocell will increase as the geocell stiffness increases, but causes a reduction in tpassive. A parametric study was also developed to investigate the impact of geocell stiffness and friction coefficient on the passive resistance and mobilised tensile strength. These results indicate that the passive resistance and mobilised tensile strength increase with the increase in overburden pressure (q) and friction coefficient (d).
\end{abstract}

\section{Keywords}

geocell, out, performance, pull, evaluation, testing, railway, stabilised, subballast

\section{Publication Details}

Biabani, M. Mahdi., Ngo, N. Trung. \& Indraratna, B. (2016). Performance evaluation of railway subballast stabilised with geocell based on pull-out testing. Geotextiles and Geomembranes, 44 (4), 579-591. 


\title{
Performance evaluation of railway subballast stabilised with geocell based on pull-out testing
}

M. Mahdi Biabani, PhD, MEng, BEng

Research Assistant, Centre for Geomechanics and Railway Engineering, University of Wollongong, Wollongong City, NSW 2522, Australia; ARC Centre for Excellence for Geotechnical Science and Engineering, Australia Faculty of Engineering, Australia

\author{
Ngoc Trung Ngo, PhD, MEng, BEng \\ Lecturer, School of Civil, Mining and Environmental Engineering, University of \\ Wollongong, Wollongong City, NSW 2522, Australia; ARC Centre for Excellence for \\ Geotechnical Science and Engineering, Australia Faculty of Engineering, Australia
}

Buddhima Indraratna, PhD (Alberta), FTSE, FIEAust., FASCE, FGS.

Research Director, Distinguished Professor of Civil Engineering, Centre for Geomechanics and Railway Engineering, University of Wollongong, Wollongong, NSW 2522, Australia.

ARC Centre for Excellence for Geotechnical Science and Engineering, Australia

Technical paper submitted to: Geotextiles and Geomembranes

(1)

Author for correspondence: Distinguished Professor Buddhima Indraratna Faculty of Engineering and Information Sciences University of Wollongong Wollongong, NSW 2522

Australia.

Ph: +61242213046

Fax: +6124221 3238

Email: indra@uow.edu.au 


\title{
Performance evaluation of railway subballast stabilised with geocell based on pull-out testing
}

\author{
M. Mahdi Biabani ${ }^{1}$, Ngoc Trung Ngo $^{2}$ and Buddhima Indraratna ${ }^{3}$ \\ ${ }^{1}$ Research Assistant, Centre for Geomechanics and Railway Engineering, Faculty of \\ Engineering, University of Wollongong, Wollongong City, NSW 2522, Australia; ARC \\ Centre for Excellence for Geotechnical Science and Engineering, Australia Faculty of \\ Engineering, Australia.Email: mmb958@uowmail.edu.au \\ ${ }^{2}$ Lecturer, School of Civil, Mining and Environmental Engineering, University of \\ Wollongong, Wollongong City, NSW 2522, Australia; ARC Centre for Excellence for \\ Geotechnical Science and Engineering, Australia Faculty of Engineering, Australia. Email: \\ trung@uow.edu.au, Ph: +61 242214892 Fax: +61 242213238 \\ ${ }^{3}$ Research Director, Distinguished Professor of Civil Engineering, Centre for Geomechanics \\ and Railway Engineering, University of Wollongong, Wollongong, NSW 2522, Australia. \\ ARC Centre for Excellence for Geotechnical Science and Engineering, Australia, Email: \\ indra@uow.edu.au, Ph: +61242213046 Fax: +61242213238
}

ABSTRACT: A large-scale apparatus was designed and built at the University of Wollongong to evaluate the pull-out strength of rail subballast reinforced with geocells. A series of tests were carried out to investigate the pull-out resistance, mobilised tensile strength ( $\tau_{\text {tensile }}$ ) and passive strength ( $\left.\tau_{\text {passive }}\right)$ of a subballast-geocell assembly under a given range of overburden pressure $(1 \mathrm{kPa} \leq q \leq 45 \mathrm{kPa})$. The interface was held in a vertical alignment to better simulate the interaction between subballast and geocell in accordance with routine track practices. The test results show that the geocell reinforcement provides a considerable degree of passive resistance, where the open area $(O A)$ and lateral pressure $\left(\sigma_{n}\right)$ over the geocell strip are found to be influential factors. A three-dimensional finite element simulation was also conducted. The numerical results show that the tensile strength mobilised in the geocell will increase as the geocell stiffness increases, but causes a reduction in $\tau_{\text {passive }}$. A parametric study was also developed to investigate the impact of geocell stiffness and friction 
coefficient on the passive resistance and mobilised tensile strength. These results indicate that the passive resistance and mobilised tensile strength increase with the increase in overburden pressure $(q)$ and friction coefficient $(\delta)$.

KEYWORDS: Geosynthetics, Geocell reinforcement, subballast, pull-out, numerical modelling

\section{Introduction}

In view of rapid urbanisation, the demand for appropriate ground improvement techniques is imperative, in order to construct road and rail infrastructure over subgrade deposits with low shear strength. This has intensified pressure on railway industry to find innovative solutions to maintain track stability and reduce maintenance cost. Unlike conventional rigid reinforcement (e.g. steel and timber), geosynthetics have shown a promising approach to improve the performance of granular media placed over weak and soft subgrade (Bergado et al. 1993; Indraratna et al. 2011; Bathurst and Raymond 1987; Brown et al. 2006; Tutumluer et al. 2012). Loss of track geometry that is associated with excessive differential settlements due to localized failure of formation (capping and subgrade), often results in reduced stability and longevity of tracks (Selig and Waters 1994, Indraratna et al. 2014). In this regard, planer geosynthetics (e.g. geogrids, geotextiles or geocomposites) have been effectively utilised to reduce excessive settlement and lateral displacement of tracks under cyclic loading (Indraratna et al. 2013). In addition, three-dimensional cellular reinforcement, also known as geocell mattress, has been considered for different applications. The improvement in the performance of geocell stabilised soil has been attributed to enhanced apparent cohesion between the infilled soil and the geocell (Bathurst and Rajagopal, 1993). Nevertheless, recent studies have proven that the additional confinement mobilised during cyclic loading, helps to 
enhance confinement and minimize lateral spreading of the aggregates, hence maintain stability of the infill granular material (Indraratna et al. 2015). Different types of geosynthetics have been utilised to investigate the pull out resistance (Ezzein and Bathurst 2014, Moraci and Recalcati 2006, Sieira et al. 2009, and Bakeer et al. 1998). Also, the effects of aperture size and shape and opening area have been investigated by employing large-scale direct shear box and assessing the shear strength of unreinforced and reinforced soil (Biabani and Indraratna 2015). Nevertheless, studies of pull-out testing on cellular reinforcement (i.e. geocell pocket) of railway materials have not been conducted before to the knowledge of the authors.

Indeed, none of the past studies were able to evaluate the exact mechanisms of shear improvement due to: (i) disparity in the loading patterns, where the overburden stress is either ignored or considered to be perpendicular to the sliding direction, and (ii) inappropriate horizontal alignment of the failure plane, in conventional direct shear and pull-out tests. In most cases, the planer geogrids are placed horizontally, so the normal stress is the vertical stress. However, placing the geocells mattress horizontally means that their strips are in the vertical direction, so the normal stress can be assumed as hydrostatic stress. This pattern of normal stress distribution must be properly assessed, because this is crucial for internal stability in the lower layers of a railway substructure, where the lateral confinement on ballast or subballast is usually very low ( $\sigma_{3}^{\prime} \leq 30 \mathrm{kPa}$ ) as measured in the field. In view of this, a fullscale laboratory pull-out apparatus was adopted to investigate the shear strength of geocellreinforced subballast in a more realistic manner.

\section{Scope and objective of current study}


In order to investigate the advantages of cellular reinforcement of geocell-reinforced subballast in the field (Fig.1), a series of pull-out tests were conducted using a new apparatus, where the overburden stress was applied parallel to the pull-out direction (shearing plane). In this condition, the load distribution over the geocell strip can be investigated and compared to a conventional direct shear or a pull-out box. The objective of this current study is to develop a new approach to measure the passive resistance $\left(\tau_{\text {passive }}\right)$ of geocell reinforced granular media with respect to a typical railway condition subjected to a relatively low confining pressure exerted by sleepers and the ballast shoulder $\left(\sigma_{3}^{\prime} \leq 30 \mathrm{kPa}\right)$ as measured in the field by Indraratna et al. (2015). In this investigation, during pull-out testing, the potential failure plane was not forced to be parallel to the pulling direction, and the mobilised shear resistance over geocell strips was measured by applying different overburden stresses on top of the geocell. A numerical analysis was also conducted to validate the experimental results and to provide greater insight into the pull-out test results, particularly considering the passive resistance $\left(\tau_{\text {passive }}\right)$ attributed to the transverse ribs and mobilised tensile strength $\left(\tau_{\text {tensile }}\right)$ of the longitudinal ribs. Also, a parametric study was carried out to investigate the impact of different factors, including the geocell stiffness $\left(E_{\text {geocell }}\right)$, the overburden pressure $(q)$, and the friction coefficient $(\delta)$.

\section{Material and Method of Testing}

The granular medium used here was a locally available crushed basalt from a quarry near Wollongong. The particle size distribution adopted for the subballast was within the rail industry specified range $\left(D_{50}=3.3 \mathrm{~mm}, D_{\max }=19 \mathrm{~mm}, D_{\min }=0.075 \mathrm{~mm}, C_{u}=16.3, C_{c}=1.3\right.$, $\gamma_{d}=19 \mathrm{kN} / \mathrm{m}^{3}$ ). Four types of geogrid and two types of geomembrane were used to form a geocell pocket for reinforcing the subballast and to examine the influence of the open area 
types of geosynthetics (Fig. 2 a): (i) geomembrane (GC1 and GC2), (ii) triaxial geogrid with triangular openings (GG1), and (iii) biaxial geogrid (GG2, GG3 and GG4). The geomembranes used were made from strips of high density polyethylene, welded together at the joints to create a cellular network with depth of $150 \mathrm{~mm}$. The geogrids were made from high density polypropylene, and they were also connected together to create a $150 \mathrm{~mm}$ deep cellular pocket. It is noted that the welding of geocells was carried out by the manufacturer. During laboratory tests, the geocell was installed exactly in the same way as in the field. Within the scope of this study, the effect of the welded joint was not considered, although we agree that this is a relevant point. The physical and mechanical properties of the geosynthetics used in this study are summarised in Table 1.

The large-scale pull-out box (800 mm long, $600 \mathrm{~mm}$ wide, and $500 \mathrm{~mm}$ high) designed and built at University of Wollongong is shown in Fig. 2b. It was large enough to accommodate a single geocell pocket at the centre without any significant boundary effects. A total of 36 tests under different overburden pressures were conducted. A predetermined mass of granular material was placed inside the box in several layers and then compacted using a vibratory hammer to achieve the desired relative density $\left(D_{R}\right)$ of about $77 \%$, that is representative of subballast in the field $\left(\rho=2100 \mathrm{~kg} / \mathrm{m}^{3}\right)$. Vertical displacement was recorded using a linear variable differential transformer (LVDT). Four strain gauges were attached to the geocell pocket at heights of $h=18.75,56.25,93.75$, and $131.25 \mathrm{~mm}$ as illustrated in Figs. 2b-c to measure vertical strains of longitudinal ribs in various geocell pockets. To attach the strain gauges to the geocell strip, the surface of a geocell pocket/rib was brushed lightly with cleaner and degreaser, and an industrial adhesive was applied before mounting the strain gauges. The strain gauge was pressed into the adhesive with an overlying thin plastic film with care to remove all the entrapped air. The strain gauges were then covered with flexible 
sealant and water proof tape. The cable leads were encased in flexible conduits to protect them from any damage during the experiments owing to subsequent deformation of the geocell pocket. Four miniature pressure cells $(10 \mathrm{~mm}$ thick, $50 \mathrm{~mm}$ diameter with a range of $500 \mathrm{kPa}$ and 99.7\% accuracy) were also mounted to the geocell at depths of $h=18.75,56.25$, 93.75 and $131.25 \mathrm{~mm}$ to measure the stress induced in the geocell strip (Figs. 2b-c). Every instrument was calibrated before connecting to an electronic data logger (DT800) and was controlled by a host computer to accurately record pull-out force, vertical displacement and stresses at predetermined time intervals during the testing. A pull-out force was applied using the tensile Instron machine at different overburden pressures varying from $1 \mathrm{kPa} \leq q \leq 45$ $\mathrm{kPa}$. A groove was provided at the top loading plate to facilitate pull-out of the geocell while maintaining a constant overburden pressure. A single pocket of geocell was placed at the centre of the box and the subballast layer was placed and compacted in three layers surrounding the geocell to achieve the desired field density. The pull-out rate was maintained at $1 \mathrm{~mm} / \mathrm{min}$ during testing, following the ASTMD-6706-01, (2001). During these experiments, shearing continued until a maximum vertical displacement of $30 \mathrm{~mm}$ was reached (i.e. the maximum displacement allowed by the apparatus).

\section{Results and Discussion}

\subsection{Pull-out force}

Fig. 3a shows the results obtained by pull-out tests for reinforced subballast with a single geocell pocket (GC1) subjected to various overburden pressures, ranging from $1 \mathrm{kPa}$ to 45 $\mathrm{kPa}$. The pull-out force shows a non-linear variation with the axial displacement where as expected, an increased pull-out force is evident at a higher overburden pressure. For a given overburden pressure, the pull-out force reaches the peak value at an axial displacement of 48mm, beyond which the pull-out force then decreases with further increase in axial 
displacement. The observed stress-strain responses including volumetric strains confirm that the reduction in the pull-out force is associated with the post-peak dilation of the aggregates. The variation in volumetric change at different axial displacements is shown in Fig. 3c and it is observed that at low overburden pressure $(q)$, geocell-reinforced specimen exhibits an initial contraction followed by dilation. Nevertheless, a volumetric contraction occurs at a higher level of overburden pressure ( $q \geq 20 \mathrm{kPa}$ ), which clearly demonstrates the role of effective cellular confinement in inhibiting dilation. The degree of contraction is increased by increasing the overburden pressure. It can be concluded that the infill granular materials tend to be in compression rather than being in dilation when reinforced by a cellular pocket.

Fig. 3b presents the corresponding pull-out force of the subballast, reinforced with different types of geosynthetics subjected to an overburden pressure of $q=20.5 \mathrm{kPa}$. According to the laboratory results, GG3 (having the highest open area) provides the lowest degree of pull-out Indraratna 2015).

207

\subsection{Measured geosynthetics strains}


It is well recognised that in pull-out testing, the strain mobilised in the geosynthetic varies according to the distance from the pull-out force (Abdi and Zandieh 2014, Moraci and Recalcati 2006, Sugimoto and Alagiyawanna 2003). During pull-out testing, the force is transferred from transverse members and friction surfaces through the longitudinal members. There will be a different mobilisation of strain, at different parts of the geocell pocket, due to different elongation of longitudinal ribs (Bergado and Chai 1994). As a result, a particular part of reinforcement will be moved during pull-out testing. Fig. 4a shows the variations of strains, mobilised in the longitudinal ribs of geogrid GG2 subjected to various overburden pressures. The experimental results show that the mobilised strain of the geocell pocket varies with the depth and that mobilised strain increases as the overburden pressures $(q)$ increases. The maximum strain mobilised in the reinforcement is found to occur at a depth of about $h=$ $18.75 \mathrm{~mm}$. Moreover, the results also shows that there is an insignificant strain mobilised at the depth of $h=131.25 \mathrm{~mm}$, highlighting the varied mobilised strains with the geocell depth. These results are in accordance with previous studies, which were carried out using conventional pull-out testing (Bergado and Chai 1994; Alagiyawanna et al. 2001), among others. Fig. 4b shows the mobilised strain for different types of the geosynthetics subjected to an overburden pressure of $q=29.5 \mathrm{kPa}$. It is seen in all of these artificial inclusions that the mobilised strain decreases with an increase in the depth of the geocell pockets. However, over the longitudinal ribs, the GG2 provided the minimum strain, and GG3 provided the maximum strain. This can be explained by the fact that GG2 has the highest and GG3 has the lowest mobilised tensile strength during pull-out testing, and this is possibly associated with the level of interlocking between the subballast particles and the tested geosynthetics. 
233 It is well known that, the pull-out resistance can be determined as the sum of the frictional 234 and bearing (passive) resistance in reinforced soil as:

$$
P_{\text {reinf orced }}=P_{R F}+P_{R B}
$$

235

236 where, $P_{R B}$ is the bearing (passive) resistance and $P_{R F}$ is the frictional resistance. There are several models available in the literature for evaluating the bearing (passive) resistance, which are summarised in Table 2. Accordingly, the performance of geocell-reinforced subballast can be explained by determining the bearing resistance (passive strength) that develops against transverse ribs during pull-out testing. Bergado and Chai (1994) presented that the mobilised passive bearing resistance ( $\tau_{\text {passive }}$ ) of geosynthetic-reinforced soil could be obtained as:

$$
\tau_{p}=N_{q} \sigma_{n}+C N_{c}
$$

244 where, $N c$ and $N_{q}$ are bearing capacity parameters. The bearing capacity factor $N_{q}$ is 245 determined by (Peterson and Anderson, 1980):

$$
N_{q}=e^{(\pi \tan \phi)} \tan ^{2}\left(\frac{\pi}{4}+\frac{\phi}{2}\right)
$$

246 Also, the value of $N_{c}$ can be determined by:

$$
N_{c}=\left(N_{q}-1\right) \cot \phi
$$

In Eq. (2), $\sigma_{n}$ is the normal stress at the soil-geocell interface, which has been measured by miniature pressure cells. The magnitude of normal stress over the geocell strip could be calculated by lateral earth pressure, as shown in Fig 5a. The passive resistance of geocell reinforced subballast determined by Eq. (2) is plotted for different overburden pressures (hence normal stresses) for various types of geosynthetics, as shown in Fig. 5b. In addition, the degree of $\sigma_{n}$ over the geocell strip measured by the miniature pressure cell and calculated 
by earth lateral pressure is also shown in Fig. 5b. As expected, the passive resistance increases as the overburden pressure $(q)$ increases. Notably, the value of $\sigma_{n}$ measured by the pressure cell is slightly greater than $\sigma_{n}$ calculated by the lateral earth pressure theory. Also, based on the lateral pressure measured by four miniature pressure cells, a marginal difference is observed over the relatively small height of the geocell pocket. Accordingly, it can be assumed that the shear strength was uniform through the geocell strips. The geogrids GG1 and GG3 provide the maximum and minimum $\tau_{\text {passive, }}$ respectively, as shown in Fig. $5 \mathrm{~b}$. This can be justified due to the optimum length and thickness of the transverse ribs compared to the subballast degradation. Fig. $5 \mathrm{~b}$ also shows that the maximum passive resistance can be obtained when the percentage of open area $(O A)$ is in a range of $70 \%<O A<80 \%$.

In order to compare the shear strength obtained by the new pull-out box and those measured in large-scale direct shear tests by Biabani and Indraratna (2015), the passive resistance is plotted against normal stress $\left(\sigma_{n}\right)$ for the same subballast confined by the same geosynthetics, as shown in Fig. 5 c. It is seen that the mobilised passive resistance ( $\left.\tau_{\text {passive }}\right)$ measured by the pull-out and direct shear tests exhibits a similar trend except that the degree of mobilised passive resistance ( $\tau_{\text {passive }}$ ) measured in the large-scale direct shear box is markedly less than that measured in the current pull-out tests. This can be related to the impact of loading mechanism on the overall behaviour of reinforced materials, where the contribution of geogrid transverse ribs has been mobilised to increase passive resistance for the case of interaction under pullout mode. It is seen from Figs. 5b-c that at the same normal stress (i.e. $\sigma_{n} \approx 21 \mathrm{kPa}$ ), the passive resistance measured in the pull-out box (about $\tau_{\text {passive }}=16 \mathrm{kPa}$ ) is much higher than that measured in the large scale direct shear box (about $\tau_{\text {passive }}=4 \mathrm{kPa}$ ). passive resistance as was exhibited during direct shear. 


\section{Finite Element Simulation}

281

282

Numerical simulations have been often used to model various types of geosynthetically reinforced soils in pull-out testing using the finite element approach (Abdi and Zandieh 2014, Ezzein and Bathurst 2014, Khedkar and Mandal 2009). However, there are only a few models that have been used to investigate the bearing (passive) resistance of soil against the transverse ribs. Due to this difficulty, most of the studies only investigated the overall performance in pull-out resistance, and the passive resistance in reinforced soil has received less attention in most of the numerical simulations currently available. To fully understand the loading mechanism and the performance of reinforced subballast in a pull-out test, it is inevitable to develop a numerical model that can capture the passive resistance of geosynthetics. A three-dimensional finite element model, using the ABAQUS package, is developed in this study to investigate the actual behaviour of geocell reinforced subballast. In order to validate the experimental results, a single pocket form by geogrid GG2 was selected for the numerical simulation. Furthermore, to simulate the exact configuration of the laboratory size pull-out test, the geometry of the box and the geocell pocket (i.e., number and dimension of the apertures) were taken to be the same as the experimental configuration (Figs. 6).

\subsection{Material properties}

An elasto-plastic material with a non-associated flow rule was used in simulations to model the subballast. To capture the plastic behaviour of subballast, the Mohr-Coulomb yield criterion with a friction coefficient of 0.5 was adopted. To model the geocell pocket, a linear elastic-perfectly plastic material was used. The geometry of the geocell reinforcement is one of the main factors considered in this pullout study where a hexagonal shape was selected for 
the geocell pocket, as it is similar to the actual geocell pocket conducted in the experiment and on the field. Also, it provides a more uniform stress distribution than a square or diamond shape when it is subjected to loading. The subballast-geocell interaction was established by developing two contact surface pairs, i.e. inside and outside of the pocket with a hard normal contact. A small value of cohesion (2 $\mathrm{kPa}$ ) was used during this simulation to improve numerical stability and to ensure the model to converge in the reasonable computation time. A summary of the material properties used in the simulations is provided in Table 3 . Exploiting the symmetry of the developed model, only half of the geocell assembly was simulated in the current analysis, as shown in Figs. 6c-d.

\subsection{Boundary conditions, loading and mesh size justification}

In the FEM simulations, the boundary conditions were applied to allow nodes in the boundary to move in a vertical direction, and these nodes were restricted from moving in the direction normal to the boundaries (i.e. lateral directions), and the base of the model was fixed as illustrated in Figs. 6a-c. In order to obtain the optimum size of mesh and element number, several models with different numbers of elements were analysed. A sensitivity analysis was performed under an overburden pressure of $q=45 \mathrm{kPa}$ and $E_{\text {subballast }}=7000 \mathrm{kPa}$ with a geocell pocket of $150 \mathrm{~mm}$ in height to evaluate the effect of mesh density. The subballast was modelled using quadratic tetrahedral elements of type C3D10, and the number of elements varying from 17,656 to 231,310. A uniform loading applied on top of the specimen before testing and then propagated throughout the assembly during the pull-out test. The mobilised tensile strengths $\left(\tau_{\text {tensile }}\right)$ of the geocell pockets for models with different number of elements were compared at a depth of $h=18.75 \mathrm{~mm}$, after the geocell pockets had been displaced by $30 \mathrm{~mm}$, as shown in Fig. 7. It is seen that the value of $\tau_{\text {tensile }}$ decreases as the number of elements $(N)$ increases, and when the number of elements exceeds about 
329100,000 elements, the reduction in the mobilised tensile strength is negligible. Based on this observation, a finite element model with $N=100,236$ elements was adopted in the current study.

\subsection{Numerical Results}

\subsubsection{Geocell displacement}

It is well known that in pull-out testing, displacement of the geosynthetic decreases with the increasing distance from the applied force. Fig. 8a shows a typical displacement of the geocell pocket during pull-out testing, and Fig.8b shows the normalised geocell displacement $(\Delta h \%)$ in the direction parallel to the pull-out force, for different overburden pressures $(q)$ plotted at different depth of geocell pocket $(h)$. Based on these results, $\Delta h$ decreases with an increase in the overburden pressure and this observation is similar to those measured in the laboratory by the strain gauges as shown in Fig. 4a. This can be justified that increasing $q$, hence the normal pressure over the geocell strip, leads to improving its resistance to the pullout force. As expected, maximum displacement occurred at the point where the geocell pocket was attached to the pull-out force.

\subsubsection{Tensile strength}

347 One of most important parameters that governs the behaviour of reinforced soil is the mobilised tensile strength ( $\left.\tau_{\text {tensile}}\right)$ in the reinforcement, which cannot be measured directly during laboratory testing. Fig. 9a shows a typical mobilised tensile strength in different parts of geocell during pull-out testing. As shown here, minor $\tau_{\text {tensile }}$ is observed in the transverse ribs, compared to the longitudinal ribs. In order to compare the $\tau_{\text {tensile }}$ at different depths $(h)$, the values of $\tau_{\text {tensile }}$ are plotted for longitudinal ribs and junctions at different overburden pressure $(q)$ for various depths as presented in Fig. 9b. It is seen that both the longitudinal 
ribs and junctions exhibit an identical trend where the magnitude of $\tau_{\text {tensile }}$ increase with an increase of the overburden pressure. The magnitude of $\tau_{\text {tensile }}$ in the junctions is observed to be almost half of that in the longitudinal ribs. In addition, the degree of $\tau_{\text {tensile }}$ decreases with an increase in the depth of the geocell pocket $(h)$, where $\tau_{\text {tensile }}$ is found to be almost negligible in both longitudinal ribs and junctions beyond $h \geq 120 \mathrm{~mm}$.

\subsubsection{Stress distribution over geocell pocket and passive resistance}

To compare the lateral pressure over the geocell strip at different overburden pressures, the magnitude of $\sigma_{n}$ over the geocell strip is plotted for different overburden pressures $(q)$, as shown in Fig. 10a. Compared to normal pressure measured by different methods, a relatively good agreement is observed, though $\sigma_{n}$ measured by the pressure cell is slightly greater than the numerical (FEM) and theoretical values. As expected, the values of normal pressure over the geocell strip increases when the overburden pressure $(q)$ increases. In every case, the value of $\sigma_{n}$ is about less than half the overburden pressure. This highlights the difference in the loading mechanism between a conventional pull-out box, in which $\sigma_{n}$ on the geosynthetics is equal to the applied pressure, and the current pull-out box.

Another factor that was investigated in the numerical analysis is the passive resistance ( $\left.\tau_{\text {passive }}\right)$ of subballast against the pull-out force. Accordingly, the value of $\tau_{\text {passive }}$ at different overburden pressures is plotted (Fig. 10b) and it shows that the magnitude of $\tau_{\text {passive }}$ is increased by increasing $q$. Using a best-fit regression analysis, the normal stress applied to the geocell strip is provided as a function of the overburden pressure (Fig. 10b). To provide more insight into passive resistance, the vertical pressure on different sections of the subballast is shown in Fig. 10(c). This shows that the mobilised passive resistance is found to be relatively uniform over the depth of the geocell pocket. This is probably because the specimen is not 
deep enough for any change in stress in the subballast, and this leads to a uniform stress distribution with depth. In addition, this figure also shows that the magnitude of stress applied to the soil inside the geocell pocket decreases slightly, about 4-5 $\mathrm{kPa}$. This is probably because the geocell can effectively confine the infill material, thus reducing the pressure transmitted to the lower soil layer. Details of the passive resistance of the soil particle trapped within the aperture are presented in Fig. 10d. As shown here, the magnitude of $\tau_{\text {passive }}$ is slightly greater at the middle of the section (about 2-3 $\mathrm{kPa}$ ) compared to the sides, and this could be attributed to less friction between subballast and longitudinal ribs than subballast itself.

\subsection{Parametric study}

\subsubsection{Geocell stiffness}

The results of this study can be used to predict the behaviour of the geocell in pull-out testing, when various types of geosynthetics with different properties are deployed. In this study, the impact of geocell stiffness $\left(E_{\text {geocell }}\right)$ is investigated by varying its modulus from a relatively low to high range of $0.05 \mathrm{GPa}$ to $5.0 \mathrm{GPa}$ to simulate the behaviour of different geosynthetics (e.g. GC1, GC2, GG1, GG3 and GG4). Moreover, the influence of the friction coefficient ( $\delta$ ) was studied from a range of 0.25 to 0.9 to simulate the relatively smooth to rough interface between the infill and the geosynthetic interface. Fig. 11a shows the variations in the mobilised tensile strength $\left(\tau_{\text {tensile }}\right.$ ) in the longitudinal ribs for different $E_{\text {geocell }}$ at different depths of the geocell pocket. As expected, by increasing the stiffness of the geocell, the magnitude of $\tau_{\text {tensile }}$ is increased. The numerical simulation shows that by increasing $E_{\text {geocell }}$ up to $1 \mathrm{MPa}$, there is a significant improvement in $\tau_{\text {tensile, }}$, beyond which any improvement is marginal (Fig. 11a). It can be concluded that deploying geosynthetics with a relatively high modulus does not provide a significant difference in behaviour, compared to one with a lower 
404

405

406

407

408

409

410

411

412

413

414

415

416

417

418

419

420

421

422

423

424

425

426

427

428

stiffness. Fig. 11a also shows that regardless of the geosynthetic stiffness, at a lower depth ( $h$ $=131.25 \mathrm{~mm}$ ), almost the same tensile strength is mobilised. Fig. $11 \mathrm{~b}$ shows the degree of mobilised tensile strength $\left(\tau_{\text {tensile }}\right)$ at different value of friction coefficient $(\delta)$ and as expected, increased $\delta$ leads to an increase in the magnitude of $\tau_{\text {tensile. }}$ It also shows that at the lower depth of the geocell ( $h \geq 90 \mathrm{~mm}$ ), in all of cases, the degree of $\tau_{\text {tensile }}$ is reduced markedly.

\subsubsection{Passive resistance}

The effect of geocell stiffness ( $\left.E_{\text {geocell }}\right)$ and friction coefficient $(\delta)$ can be best evaluated by comparing the passive resistance $\left(\tau_{\text {passive }}\right)$ provided by the transverse ribs during pull-out testing. Fig. 12a presents the developed $\tau_{\text {passive }}$ against the transverse rips for geocell with different values of stiffness $\left(E_{\text {geocell }}\right)$. Based on these results, the maximum passive strength is observed at the lowest value of $E_{\text {geocell }}$. Increasing $E_{\text {geocell }}$ leads to a substantial reduction in the passive resistance against the transverse ribs. This can be explained by the fact that there will be a higher $\tau_{\text {tensile }}$ mobilised in geocell at a higher value of $E_{\text {geocell. }}$. As result, this will help to increase the stability of the reinforced subballast and lead to a reduction in the passive resistance. This behaviour continues up to about $E_{\text {geocell }}=1000 \mathrm{MPa}$, beyond which no significant reduction is observed. This is because no further $\tau_{\text {tensile }}$ is mobilised at the geocell with a higher stiffness $\left(E_{\text {geocell }} \leq 1000 \mathrm{MPa}\right)$. Thereby, it can be concluded that geosynthetics with a lower stiffness can provide a higher magnitude of passive resistance during pull-out testing. Fig. $12 \mathrm{~b}$ presents the degree of passive resistance $\left(\tau_{\text {passive }}\right)$ at different friction coefficients $\left(\delta\right.$ ) for different overburden pressures $(q)$. The magnitude of $\tau_{\text {passive }}$ increases as a result of enhanced $\delta$ at different values of q. The degree of $\tau_{\text {passive }}$ determined by Eq. (2) is also presented in Fig. 12b where it is found that the magnitude of $\tau_{\text {passive }}$ calculated by Eq. (2) is in a good agreement with the numerical results when the friction coefficient is within the range of $0.4 \leq \delta \leq 0.45$. 


\section{Practical implications}

430 It is found from this study that geocell modulus, value of friction coefficient and loading mechanism have considerable influence on the performance of geocell-reinforced subballast.

432 These influential factors need to be considered in track design in determining the mobilised 433 tensile strength and passive resistance when geocells are utilised. For this purpose, largescale pull-out tests were carried out to examine the pull-out resistance, mobilised tensile strength, and passive strength of the geocell-reinforced subballast under a realistic range of overburden pressure (1 $\mathrm{kPa}$ to $45 \mathrm{kPa}$ ). The measured data were used to calibrate and validate the three-dimensional finite element analysis.

The proposed 3D-FEM model can be used in practice for real-life scenarios to simulate pullout tests on cellular reinforcement (i.e. geocell pocket) for subballast aggregates, modelling the actual stress conditions acting on the geocells, thereby capturing the role of influencial factors as mentioned above. This model is also helpful for the practitioner to assess the mobilised tensile strength of a geocell-reinforced granular assembly, considering the passive resistance attributed to the transverse ribs and the mobilised tensile strength of the longitudinal ribs. The 3D FEM model is also able to capture the mobilised strains with the depth of geocells as accurately validated by extensive large-scale pull-out tests. In the absence of past pull-out tests on subballast reinforced by a geocell assembly, this study offers some original insight for the practitioner to improve design as well as to conduct a performance verification of the track.

\section{Conclusion}

451 The behaviour of geocell-reinforced subballast was investigated using a new pull-out apparatus under varying overburden stress $(1 \mathrm{kPa} \leq q \leq 45 \mathrm{kPa})$. A numerical analysis was conducted to simulate and measure the mobilised tensile strength and passive resistance at 
different overburden pressures, geocell modulus, and friction coefficients. A parametric study was also developed to investigate the impact of geocell stiffness and friction coefficient on the passive resistance and mobilised tensile strength. The results showed that the geocell reinforcement provided a considerable degree of passive resistance, where the open area and lateral pressure over geocell strip were found to be most influential factors. The results confirmed that the behaviour of geocell-reinforced granular medial was governed by the loading mechanism, whereby the magnitudes of friction coefficient and geocell modulus had a significant impact on the performance of the reinforced specimen.

462

This study also proved that geocells yield to higher passive resistance when they are used in pull-out testing, compared to the results obtained using the large-scale direct shear apparatus. This can be related to the impact of loading mechanism on the overall behaviour of reinforced materials where the contribution of geogrid transverse ribs has been mobilised to provide significant passive resistance during pull-out. The results also showed that the cellular reinforcement provided a higher bearing resistance in pull-out testing, in comparison with planar geomembranes tested in direct shear. It was also found that the passive bearing resistance had a significant influence on the overall interface shear strength where the lower geosynthetics stiffness resulted in a higher magnitude of passive resistance. Geocells provided a higher passive resistance when subjected to a relatively lower normal stress while the geocell with a higher stiffness exhibited a greater passive resistance against the transverse 474 ribs.

\section{Acknowledgments}

477 The authors to acknowledge the financial support received from the Research Centre for 478 Geomechanics and Railway Engineering (GRE) and the Australian Research Council (ARC). 
479 The authors are grateful for Alan Grant, Laboratory Manager and Ritchie McLean, Technical

480 Officer at GRE for their assistance during laboratory testing.

481

482

\section{List of Notations}

$$
\begin{aligned}
& A=\text { aperture size }(\mathrm{mm}) \\
& D_{50}=\text { average particle size }(\mathrm{mm}) \\
& \rho=\operatorname{density}\left(\mathrm{kg} / \mathrm{m}^{3}\right) \\
& C_{u}=\text { uniformity coefficient (dimensionless) } \\
& C c=\text { coefficient of curvature (dimensionless) } \\
& D_{R}=\text { relative density (\%) } \\
& D_{\max }=\text { maximum particle size }(\mathrm{mm}) \\
& D_{\min }=\text { minimum particle size }(\mathrm{mm}) \\
& \gamma_{d}=\text { dry unit weight of the soil }\left(\mathrm{kN} / \mathrm{m}^{3}\right) \\
& d=\text { diameter of geocell pocket }(\mathrm{mm}) \\
& \sigma_{n}=\text { normal stress }(\mathrm{kPa}) \\
& O A=\text { percentage of opening area (\%) } \\
& P=\text { pull-out force }(\mathrm{kN}) \\
& h=\text { geocell height }(\mathrm{mm}) \\
& q=\text { overburden pressure }(\mathrm{kPa}) \\
& E_{\text {geocell }}=\text { geocell stiffness }(\mathrm{MPa}) \\
& \Delta h=\text { normalised geocell displacement (\%) } \\
& v=\text { poisson's ratio } \\
& \psi=\text { dilation angle (degree) } \\
& \phi=\text { friction angle (degree) } \\
& c=\text { cohesion }(\mathrm{kPa}) \\
& \tau_{\text {passive }}=\text { passive resistance }(\mathrm{kPa}) \\
& \tau_{\text {tensile }}=\text { mobilised tensile strength }(\mathrm{MPa}) \\
& \delta=\text { friction coefficient } \\
& l_{\text {pull-out }}=\text { pull-out displacement (\%) } \\
& k_{0}=\text { coefficient of earth pressure }(\mathrm{kPa}) \\
& N=\text { number of elements }
\end{aligned}
$$




\section{References:}

509 Abdi, M. R. and Zandieh, A. R., 2014. Experimental and numerical analysis of large scale pull out tests conducted on clays reinforced with geogrids encapsulated with coarse material. Geotextiles and Geomembranes. 42(5), 494-504.

Alagiyawanna, A. M. N., Sugimoto, M., Sato, S. and Toyota, H., 2001. Influence of longitudinal and transverse members on geogrid pull-out behavior during deformation. Geotextiles and Geomembranes. 19(8), 483-507.

ASTM Standard D4885, 2011. Standard test method for determining performance strength of geomembranes by the wide strip tensile method. ASTM International, West Conshohocken, PA

ASTM Standard D5199, 2012. Standard test method for measuring the nominal thickness of geosynthetics. ASTM International, West Conshohocken, PA

ASTM Standard D6637, 2011. Standard test method for determining tensile properties of geogrids by the single or multi-rib tensile method. ASTM International, West Conshohocken, PA

ASTMD-6706-01, 2001. Standard test method for measuring geosynthetic pull-out resistance in soil. ASTM International, West Conshohocken, PA.

Bakeer, R. M., Sayed, S. M., Cates, P. and Subramanian, R., 1998. Pullout and shear tests on geogrid reinforced lightweight aggregate. Geotextiles and Geomembranes. 16(2), 119133.

Bathurst, R. J. Karpurapu, R. 1993. Large-scale triaxial compression testing of geocellreinforced granular soils. Geotechnical Testing Journal., 16(3), 296-303. 
Bathurst, R. J. and Raymond, G. P., 1987. Geogrid reinforcement of ballasted track. Transportation Research Record. 1153: 8-14.

Bergado, D. T., Bukkanasuta, A. and Balasubramaniam, A. S., 1987. Laboratory pull-out tests using bamboo and polymer geogrids including a case study. Geotextiles and Geomembranes. 5(3), 153-189.

Bergado, D. T., Chai, J. C., Abiera, H. O., Alfaro, M. C. and Balasubramaniam, A. S., 1993. Interaction between cohesive-frictional soil and various grid reinforcements. Geotextiles and Geomembranes. 12(4), 327-349.

Bergado, D. T. and Chai, J. C., 1994. Pullout force/displacement relationship of extensible grid reinforcements. Geotextiles and Geomembranes. 13(5), 295-316.

Bergado, D. T. and Teerawattanasuk, C., 2001. Analytical models for predicting the pullout capacity and interaction between hexagonal wire mesh and silty sand backfill. Tamkang Journal of Science and Engineerin. 4(4), 227-238.

Brown, S. F., Thom, N. H. , and Kwan, J., 2006. Optimising the geogrid reinforcement of rail track ballast. Railfound Conference, Birmingham. pp. 346-354.

Biabani, M. M. and Indraratna, B., 2015. An evaluation of the interface behaviour of rail subballast stabilised with geogrids and geomembranes. Geotextiles and Geomembranes. 43(3), 240-249.

Chai, J. C., 1992. Interaction between grid reinforcement and cohesive-frictional soil and performance of reinforced wall/embankment on soft ground. Dissertation, Department of Engineering, Asian Institute of Technology, Bangkok, Thailand.

Ezzein, F. M. and Bathurst, R. J., 2014. A new approach to evaluate soil-geosynthetic interaction using a novel pullout test apparatus and transparent granular soil. Geotextiles and Geomembranes 42(3), 246-255. 
554 Gurung, N. and Iwao, Y., 1999. Numerical simulation of pullout response for planar soil reinforcements. Canadian Geotechnical Journal. 36(3), 455-466.

556
Indraratna, B., Ngo, N. T. , and Rujikiatkamjorn, C., 2011. Behavior of geogrid-reinforced ballast under various levels of fouling. Geotextiles and Geomembranes. 29(3), 313-322.

Indraratna, B., Ngo, N. T , and Rujikiatkamjorn, C., 2013. Deformation of coal fouled ballast stabilized with geogrid under cyclic load. Journal of Geotechnical and Geoenvironmental Engineering. 139(8), 1275-1289.

Indraratna, B., Ngo, N. T, Rujikiatkamjorn, C. , and Vinod, J. (2014). "Behavior of fresh and fouled railway ballast subjected to direct shear testing: Discrete Element Simulation". International Journal of Geomechanics. 14(1): 34-44.

Indraratna, B., Biabani, M. M. and Nimbalkar, S., 2015. Behaviour of geocell reinforced subballast subjected to cyclic loading in plane strain condition. Journal of Geotechnical \& Geoenvironmental Engineering, ASCE. 141(1), 04014081-1-04014081-16.

Indraratna, B. and Nimbalkar, S., 2013. Stress-strain degradation response of railway ballast stabilized with geosynthetics. Journal of Geotechnical \& Geoenvironmental Engineering, ASCE. 139(5), 684-700.

Jewell, R. A., 1990. Reinforcement bond capacity. Géotechnique. 40(3), 513-518.

Khedkar, M. S. and Mandal, J. N. 2009. Pullout behaviour of cellular reinforcements. Geotextiles and Geomembranes. 27(4), 262-271.

Moraci, N. and Recalcati, P., 2006. Factors affecting the pullout behaviour of extruded geogrids embedded in a compacted granular soil. Geotextiles and Geomembranes. 24(4), 220-242.

Ngo, N. T., Indraratna, B. , and Rujikiatkamjorn, C., 2014. DEM simulation of the behaviour of geogrid stabilised ballast fouled with coal. Computers and Geotechnics. 55(2014), 224-231. 
579 Peterson, L. M. \& Anderson, L. R., 1980. Pullout resistance of welded wire mesh embedded in soil. Research report submitted to Hilfiker Pipe Co., Department of Civil Engineering, Utah State University, Logan, UT, USA.

582 Selig, E. T. , and Waters, J. M. 1994. Track geotechnology and substructure management, 583 Thomas Telford, London.

584 Sieira, A. C. C. F., Gerscovich, D. M. S. and Sayão, A. S. F. J., 2009. Displacement and load 585 transfer mechanisms of geogrids under pullout condition. Geotextiles and Geomembranes. 27(4), 241-253.

587 Sugimoto, M. and Alagiyawanna, A. M. N., 2003. Pullout Behavior of Geogrid by Test and 588 Numerical Analysis. Journal of Geotechnical and Geoenvironmental Engineering. 129(4), 361-371.

590 Tutumluer, E., Huang, H. , and Bian, X. (2012). Geogrid-aggregate interlock mechanism 591 investigated through aggregate imaging based discrete element modeling approach. International Journal of geomechanics, ASCE. 12(4): 391-398. 
595 List of Tables

596 Table 1. Physical characteristics and technical specification of geocell used for the study.

597 Table 2. Summary of proposed models for capturing bearing resistance.

598 Table 3. Finite element properties of subballast and geocell used in current study.

599

600

601

602

603

604

605

606

607

608

609

610

611

612

613

614

615

616

617

618

619 
Figure 1. Loading mechanism of geocell-reinforced subballast in a typical railway environment.

623 Fig. 2. (a) Schematic illustration of (a) different geocell pockets used in this study and (b)

624 schematic diagram of large-scale pull-out box apparatus $(800 \times 600 \times 500 \mathrm{~mm})$ and (c) subballast reinforced with GG2.

Figure 3. Comparison between pull-out force and vertical strain $\left(\varepsilon_{\mathrm{v}}\right)$ of reinforced subballast.

Figure 4. Variation of mobilised strain in longitudinal ribs at (a) reinforced subballast with GG2 and (b) different types of geosynthetics.

629

Figure 5. (a) Typical stress characteristic for pull-out bearing failure (Modified after Bergado and Chai, 1994); comparison of passive resistance ( $\left.\tau_{\text {passive }}\right)$ at different opening area $(O A)$ of different geosynthetics in: (b) current pull-out box, and (c) large-scale direst shear box. Figure 6. Finite lement discretization of full mesh ( $a$ and $b$ ) and half mesh (c and d) exployting symmetry

634 Figure 7. Mobilised tensile strength predicted by FEM model with different number of elements $(\mathrm{N})$.

Figure 8. (a) Typical geocell displacement during pullout force, and (b) variation of axial displacement of longitudinal ribs at different depth of geocell pocket. Figure 9. Typical mobilised tensile stregnth in (a) geocell formed by geogeid GG2 and (b) at different depths of geocell pocket.

Figure 10. Normal stress developed over geocell strips induced by the overburden pressure, (b) passive resistance at different overburden pressures, (c) typical normal stress in the geocell-renforced subballast and (d) passive resistacne in the soil trapped in the geocell apperture. 
644 Figure 11. Variation of mobilised tensile strength at different (a) geocell stiffnesses $\left(E_{\text {geocell }}\right)$

645 and (b) friction coefficient $(\delta)$.

646 Figure 12. Variation of passive resistance at different (a) geocell stiffnesses $\left(E_{\text {geocell }}\right)$ and (b)

647 friction coefficient ( $\delta)$.

648

649

650

651

652

653

654

655

656

657

658

659

660

661

662

663

664

665

666

667

668 


\begin{tabular}{|c|c|c|c|c|c|c|}
\hline \multirow{2}{*}{ Geosynthetic type } & \multicolumn{2}{|c|}{ Geomembrane } & \multicolumn{4}{|c|}{ Geogrid } \\
\hline & GC1 & GC2 & GG1 & GG2 & GG3 & GG4 \\
\hline Material & $\mathrm{PE}$ & $\mathrm{PE}$ & $\mathrm{PP}$ & $\mathrm{PP}$ & $\mathrm{PP}$ & $\mathrm{PP}$ \\
\hline Structure & $\begin{array}{l}\text { Perforated, } \\
\text { textured strip }\end{array}$ & $\begin{array}{l}\text { Perforated, } \\
\text { textured strip }\end{array}$ & Triaxial & Biaxial & Biaxial & Biaxial \\
\hline \multicolumn{7}{|c|}{ Technical Characteristics } \\
\hline $\begin{array}{l}\text { Tensile strength } \\
\text { at } 5 \% \text { strain } \\
(\mathrm{kN} / \mathrm{m})\end{array}$ & 7.5 & 5 & 11 & 16.5 & 17.5 & 15.5 \\
\hline $\begin{array}{l}\text { Ultimate strength } \\
(\mathrm{kN} / \mathrm{m}) \\
(\mathrm{MD} / \mathrm{CMD})\end{array}$ & $9.5 \%$ & $6.5 \%$ & $19^{\mathrm{b}} / 19^{\mathrm{b}}$ & $30^{\mathrm{b}} / 30^{\mathrm{b}}$ & $30^{\mathrm{b}} / 30^{\mathrm{b}}$ & $30^{\mathrm{b}} / 30^{\mathrm{b}}$ \\
\hline \multicolumn{7}{|c|}{ Physical Characteristics } \\
\hline Open Area (\%) & 15.83 & 22.97 & 75.18 & 77.97 & 81.17 & 79.02 \\
\hline $\mathrm{A} / \mathrm{D}_{50}$ & 3.03 & 3.03 & 10.90 & 11.21 & 19.54 & 13.33 \\
\hline Aperture shape & circle & circle & Triangle & Square & Rectangle & Square \\
\hline $\begin{array}{l}\text { Aperture size } \\
(\mathrm{mm})\end{array}$ & 10 & 10 & 37 & 37 & $63.5 \times 64.5$ & 44 \\
\hline Cell depth (mm) & 150 & 150 & 150 & 150 & 150 & 150 \\
\hline Thickness (mm) & $1.5^{\mathrm{C}}$ & $1.5^{\mathrm{C}}$ & - & - & - & - \\
\hline $\begin{array}{l}\text { Rib thickness } \\
\text { (mm) (MD/CMD) }\end{array}$ & $-/-$ & $-/-$ & $2^{\mathrm{c}} / 2^{\mathrm{c}}$ & $2.2^{\mathrm{C}} / 1.3^{\mathrm{c}}$ & $2.3^{\mathrm{C}} / 1.3^{\mathrm{c}}$ & $1.0^{\mathrm{C}} / 1.0^{\mathrm{C}}$ \\
\hline
\end{tabular}

670

671 Note: PP: polypropylene, PE: Polyethylene, MD: Machine Direction, CMD: Cross Machine

672 Direction Note: ${ }^{\mathrm{a}} \mathrm{ASTM}$ 4885; ${ }^{\mathrm{A}} \mathrm{ASTM}$ 6637; ${ }^{\mathrm{c}}$ ASTM 5199

673

674

675 
Table 2. Summary of proposed models for capturing bearing resistance

\begin{tabular}{|c|c|c|}
\hline Reference & Bearing (passive ) resistance & Parameters \\
\hline Jewell (1990) & $P_{R B}=\left(\frac{L_{r}}{S}\right) \alpha_{b} H \times\left(e^{\left(\pi \tan \phi^{\prime}\right)} \tan ^{2}\left(45+\frac{\phi^{\prime}}{2}\right) \sigma_{n}^{\prime}\right)$ & $\begin{array}{l}S=\text { spacing between bearing members; } \alpha \text { b the fraction of total } \\
\text { area available for bearing; } H=\text { the height of the reinforcement. }\end{array}$ \\
\hline Chai (1992) & $\sigma_{b}=\frac{d_{n}}{\left(\frac{1}{E_{i p}}+\frac{d_{n}}{\sigma_{\text {bult }}}\right)}$ & $\begin{array}{l}P_{R B(d s)}=\text { pullout bearing load; } d_{n}=\text { normalised displacement } \\
E_{i p}=\text { the initial slope of bearing resistance curve; } \sigma_{b u l t}=\text { is the } \\
\text { ultimate value of the bearing stress. }\end{array}$ \\
\hline $\begin{array}{l}\text { Bergado et al. } \\
\text { (1987) }\end{array}$ & $F_{b}=m A_{b} N_{c} C_{u}$ & $\begin{array}{l}m=\text { total number of the transverse members; } N_{c}=\text { the bearing } \\
\text { capacity factor for a strip footing embedded in the soil; } A_{b}=\text { the } \\
\text { cross sectional area perpendicular to direction of pull of the } \\
\text { individual transverse members; } C_{u}=\text { undrained cohesion strength }\end{array}$ \\
\hline $\begin{array}{l}\text { Moraci and } \\
\text { Gioffrè (2006) }\end{array}$ & $P_{R B}=n_{t} n_{t b} A_{b} \sigma_{b}^{\prime}$ & $\begin{array}{l}n_{t}=\text { number of geogrid bearing members; } n_{t b}=\text { number of nodes in } \\
\text { as transverse element; } A_{b}=\text { area of each rib element; } \sigma_{b}^{\prime}=\text { effective } \\
\text { bearing stress on the geogrid bearing members }\end{array}$ \\
\hline $\begin{array}{l}\text { Gurung and Iwao } \\
\text { (1999) }\end{array}$ & $T_{b}=A_{b}\left(C N_{c}+\sigma_{n}^{\prime} N_{q}\right)(1-D I)$ & $\begin{array}{l}C=\text { cohesion of soil; } A_{b}=\text { is the bearing area of the transverse } \\
\text { members; } N_{q} \text { and } N_{c}=\text { bearing capacity factor; } D I=\text { the degree of } \\
\text { interface }\end{array}$ \\
\hline $\begin{array}{l}\text { Bergado and Jin- } \\
\text { Chun (1994), } \\
\text { Bergado et al. } \\
\text { (1993) }\end{array}$ & $\sigma_{b m}=c N_{c}+\sigma_{n} N_{q}$ & $\begin{array}{l}N_{q} \text { and } N_{c}=\text { bearing capacity factor; =cohesion of soil; } \sigma_{n}=\text { normal } \\
\text { stress }\end{array}$ \\
\hline $\begin{array}{l}\text { (Bergado and } \\
\text { Teerawattanasuk } \\
\text { 2001) }\end{array}$ & $P_{b}=L \sin (\alpha / 2-\theta) \times\left[\frac{U_{m}}{\frac{1}{E_{i p}}+\frac{U_{m}}{D \cdot \sigma_{u l t}}}+\frac{L \sin (\theta / 2)}{\frac{1}{E_{i p}}+\frac{2 \cdot L \sin (\theta / 2)}{D \cdot \sigma_{u l t}}}\right.$ & $\begin{array}{l}\sigma_{\text {ult }}=\text { ultimate bearing strength; } E_{i p}=\text { initial slope of pull-out } \\
\text { bearing resistance; } D=\text { diameter of transverse member; } L=\text { length } \\
\text { of single transverse member; } \theta=\text { the rotational angle of a single } \\
\text { transverse member; } \alpha=\text { initial angle of the transverse element; } \\
\text { displacement due to deformation }\end{array}$ \\
\hline
\end{tabular}


Table 3. Finite element properties of subballast and geocell used in current study

\begin{tabular}{|c|c|c|c|c|c|}
\hline \multicolumn{6}{|c|}{ Subballast } \\
\hline $\begin{array}{l}\text { Density } \\
\left(\mathrm{kg} / \mathrm{m}^{3}\right)\end{array}$ & $\begin{array}{l}\text { Poisson’s } \\
\text { Ratio, } v\end{array}$ & $\begin{array}{l}\text { Elastic } \\
\text { modulus } \\
(\mathrm{MPa})\end{array}$ & $\begin{array}{l}\text { Cohesion yield } \\
\text { stress }(\mathrm{kPa})\end{array}$ & $\begin{array}{l}\text { Angle of } \\
\text { dilation, } \psi \\
\text { (degree) }\end{array}$ & $\begin{array}{l}\text { Friction angle, } \\
\varphi \text { (degree) }\end{array}$ \\
\hline 1,955 & 0.3 & 7 & 2 & 4 & 39 \\
\hline \multicolumn{6}{|c|}{ Geocell (GG2) } \\
\hline \multicolumn{2}{|c|}{ Density $\left(\mathrm{kg} / \mathrm{m}^{3}\right)$} & \multicolumn{2}{|c|}{ Poisson's Ratio, $v$} & \multicolumn{2}{|c|}{ Elastic modulus, $E_{\text {geocell }}(\mathrm{MPa})$} \\
\hline \multicolumn{2}{|l|}{950} & \multicolumn{2}{|l|}{0.3} & \multicolumn{2}{|l|}{$50-5,000$} \\
\hline \multicolumn{6}{|l|}{ Plate } \\
\hline \multicolumn{2}{|c|}{ Density $\left(\mathrm{kg} / \mathrm{m}^{3}\right)$} & \multicolumn{2}{|c|}{ Poisson's Ratio, $v$} & \multicolumn{2}{|c|}{ Elastic modulus, $E_{\text {plate }}(\mathrm{MPa})$} \\
\hline \multicolumn{2}{|l|}{2,000} & \multicolumn{2}{|l|}{0.3} & \multicolumn{2}{|l|}{500,000} \\
\hline \multicolumn{6}{|c|}{ Subballast-geocell interface parameters } \\
\hline \multicolumn{2}{|c|}{$\overline{E_{\text {slip tolerance }}}$} & \multicolumn{4}{|c|}{ Friction coefficient, $\delta$} \\
\hline \multicolumn{2}{|l|}{0.005} & \multicolumn{4}{|c|}{$0.25-0.9$} \\
\hline
\end{tabular}


shear strength developed by interface resistance

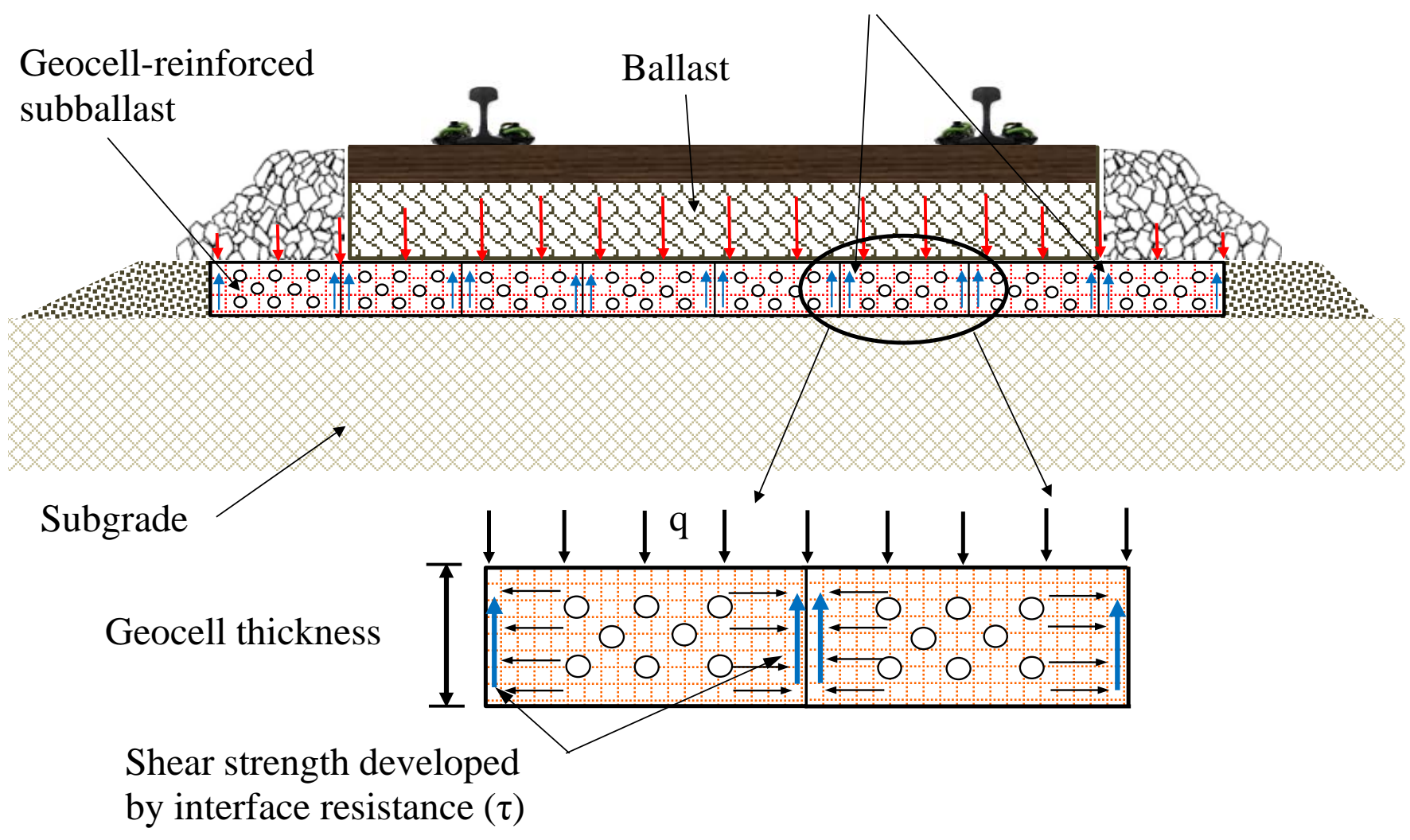

Figure 1. Loading mechanism of geocell-reinforced subballast in a typical railway environment. 


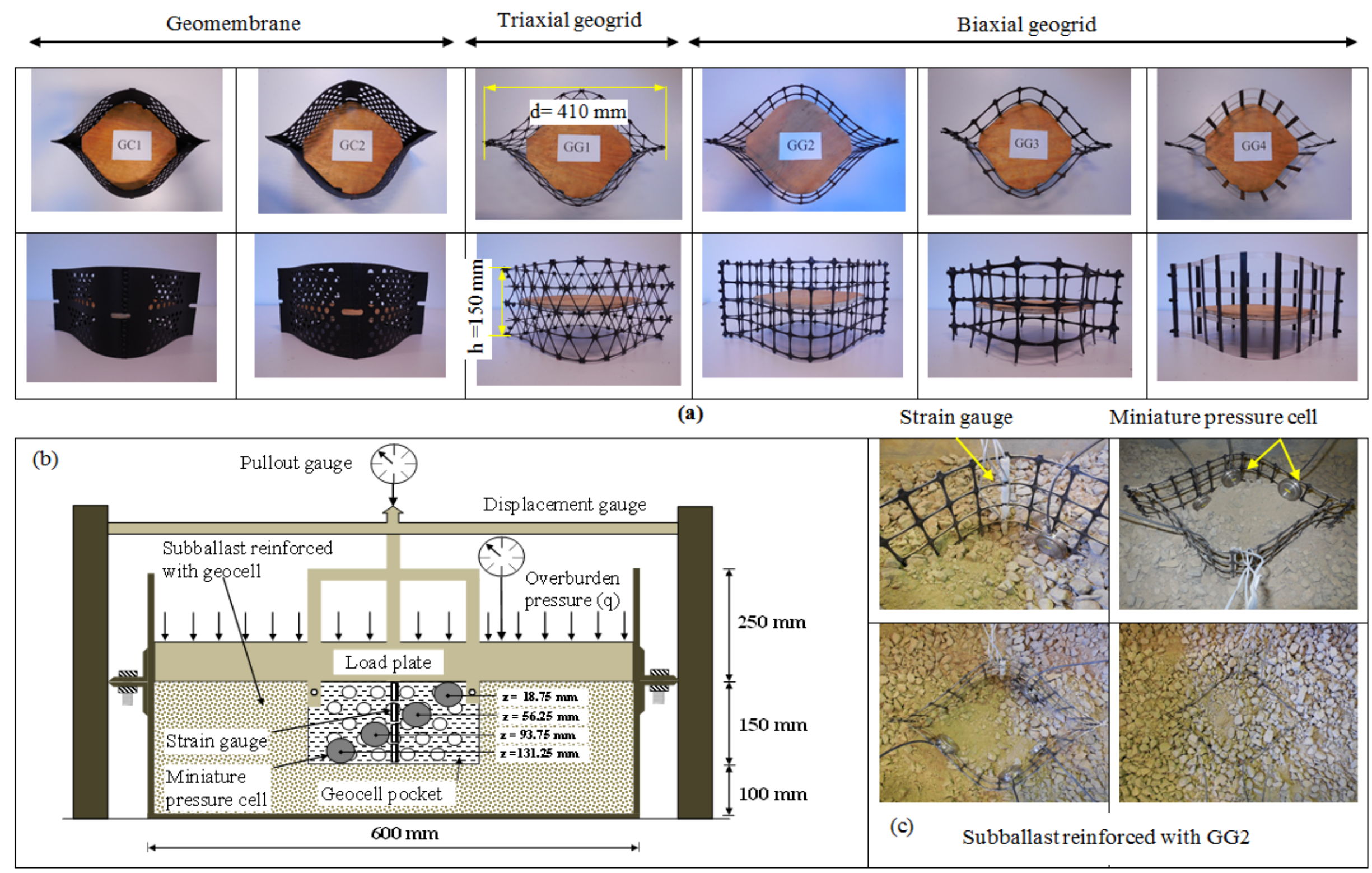

Fig. 2. (a) Schematic illustration of (a) different geocell pockets used in this study and (b) schematic diagram of large-scale pull-out box apparatus $(800 \times 600 \times 500 \mathrm{~mm})$ and (c) subballast reinforced with GG2. 

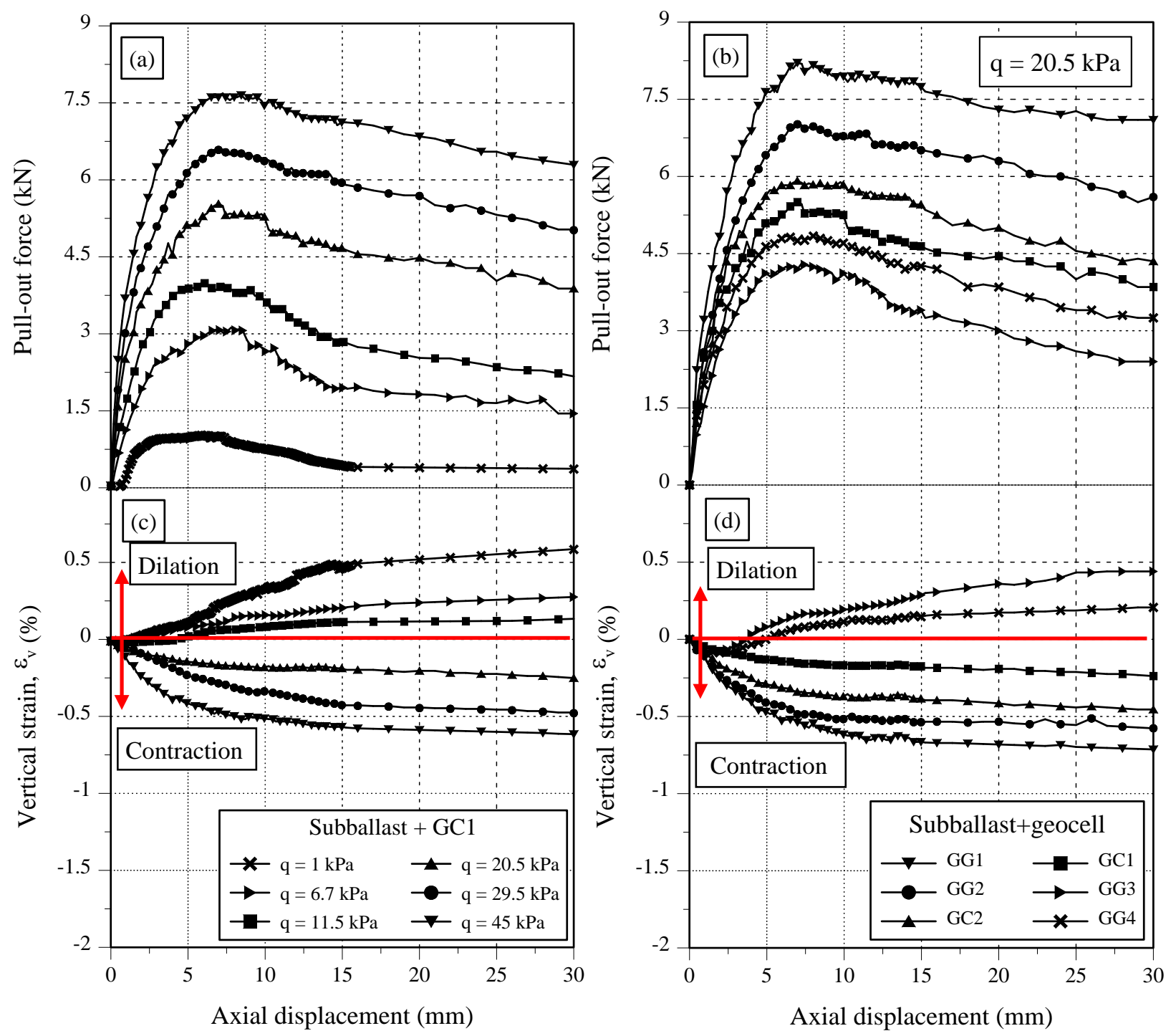

Fig. 3. Comparison between pull-out force and vertical strain $\left(\varepsilon_{v}\right)$ of reinforced subballast. 


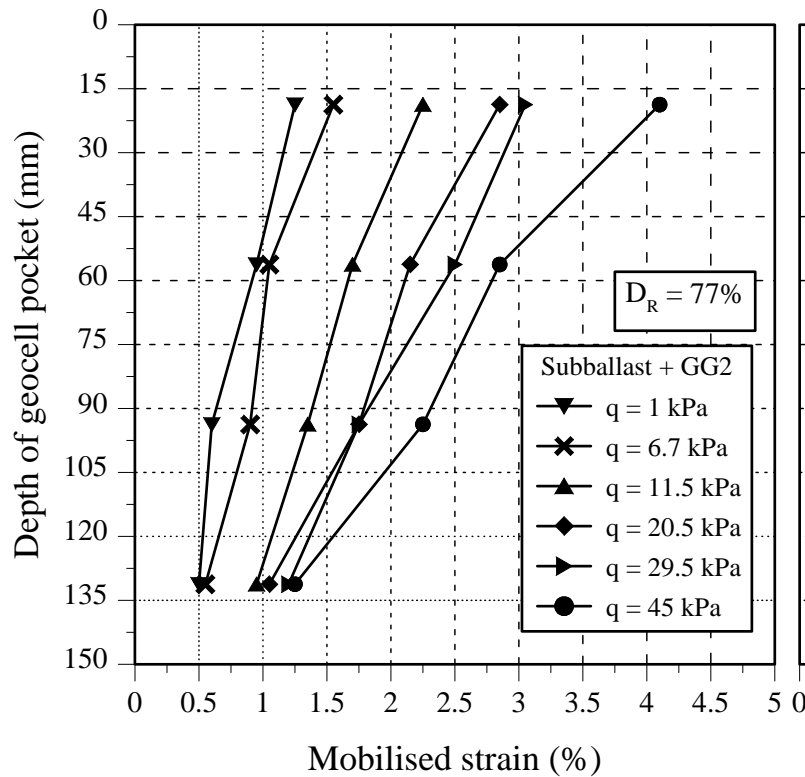

(a)

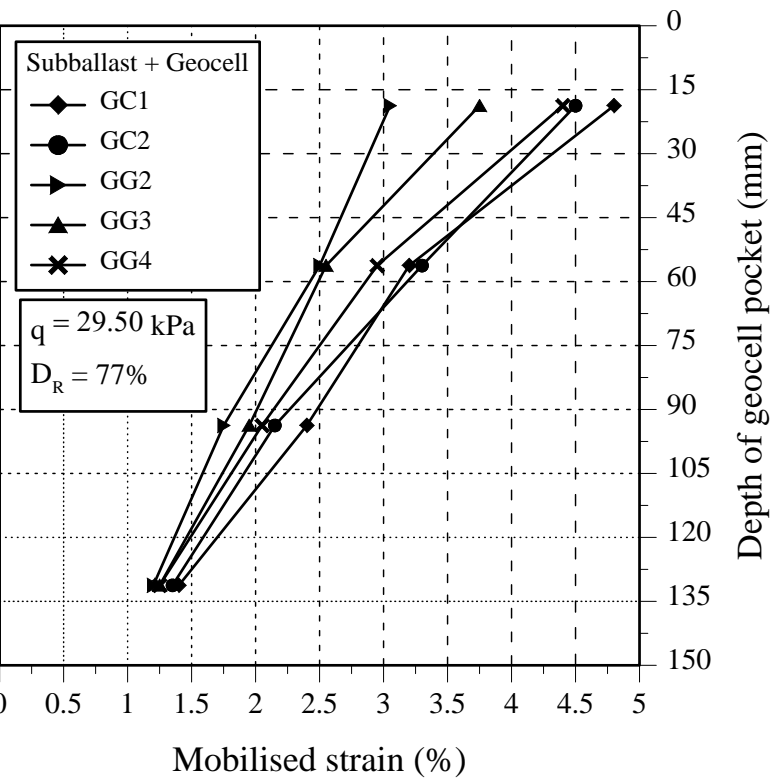

(b)

Figure 4. Variation of mobilised strain in longitudinal ribs at (a) reinforced subballast with GG2 and (b) different types of geosynthetics. 


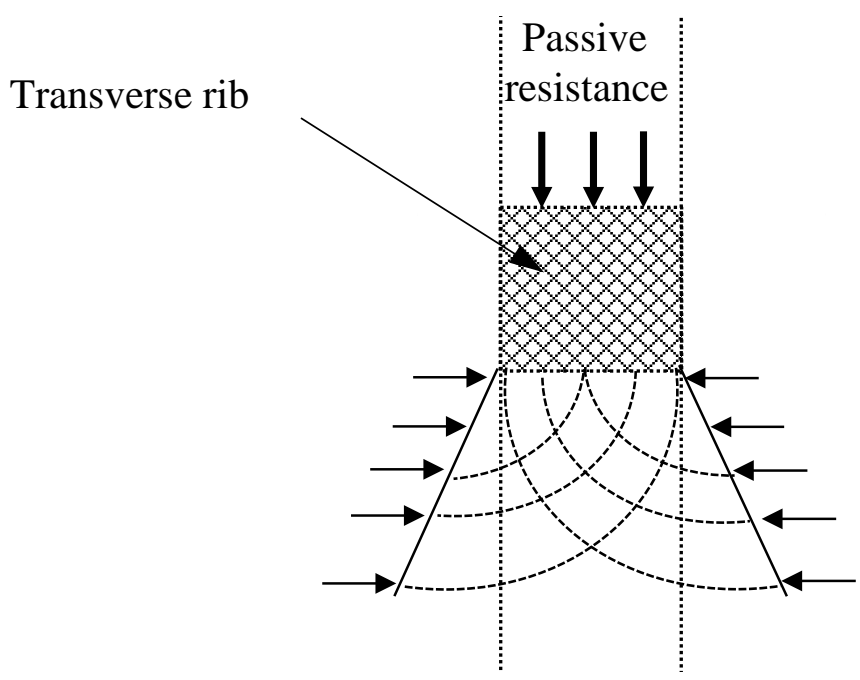

(a)

(Modified after Bergado and Chai, 1994)

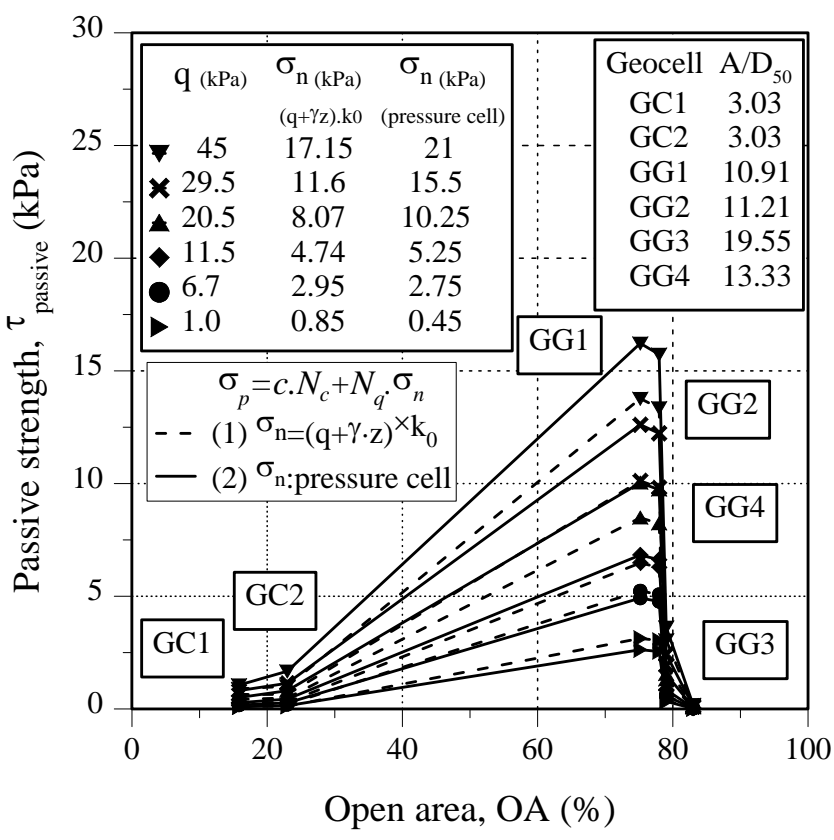

(b)

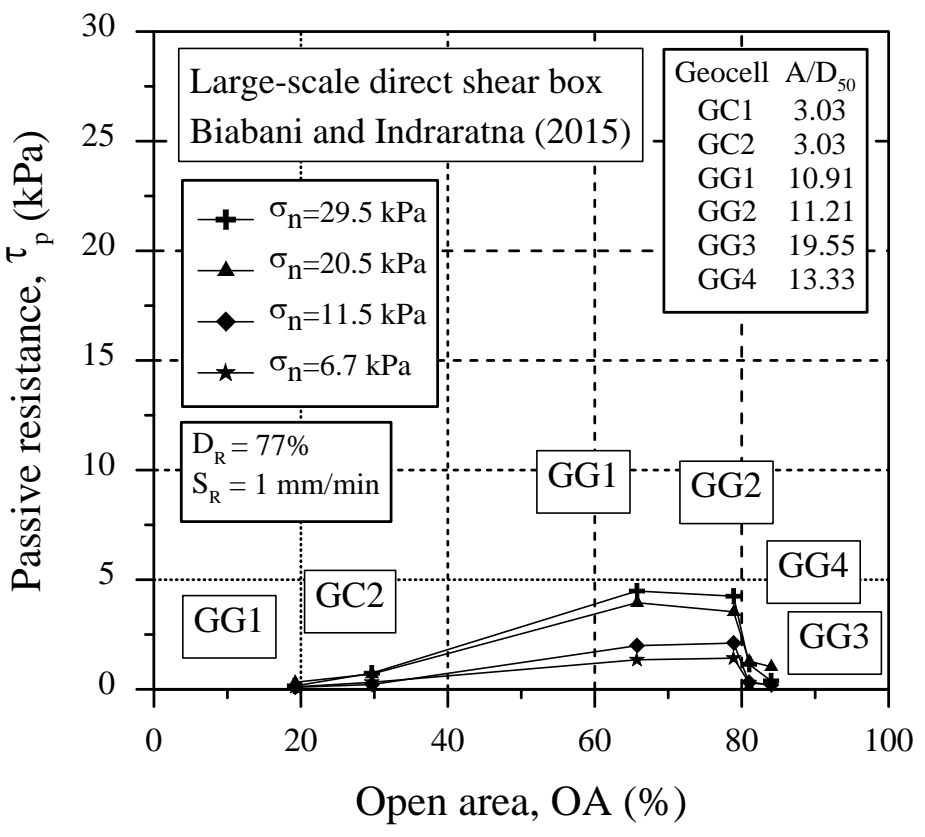

(c)

Figure 5. (a) Typical stress characteristic for pull-out bearing failure; comparison of passive resistance ( $\tau_{\text {passive }}$ ) at different opening area $(O A)$ of different geosynthetics in: (b) current pull-out box, and (c) large-scale direst shear box. 


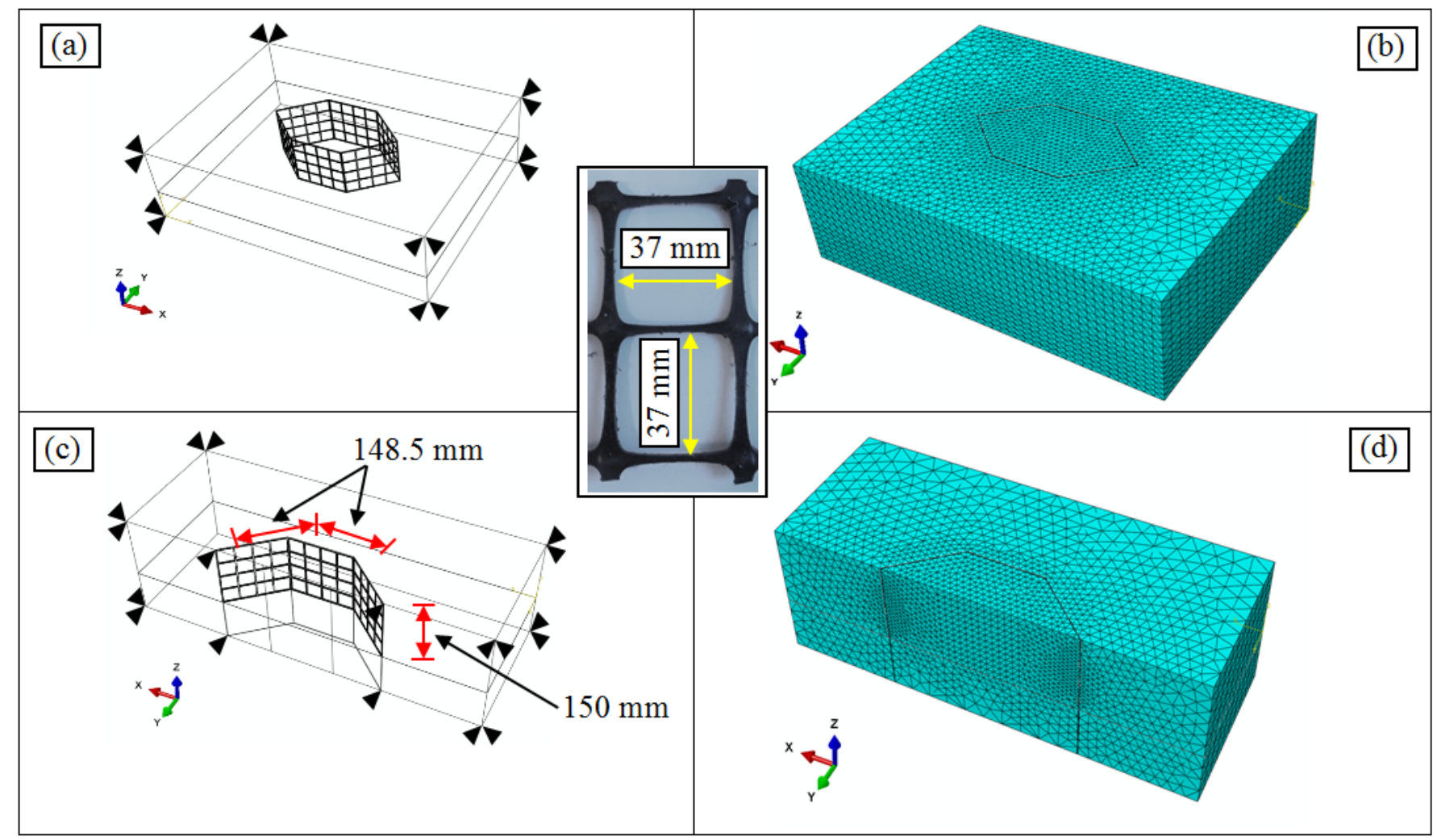

Figure 6. Finite lement discretization of: Full mesh ( $a$ and b); and half mesh (c and d) exploiting symmetry 


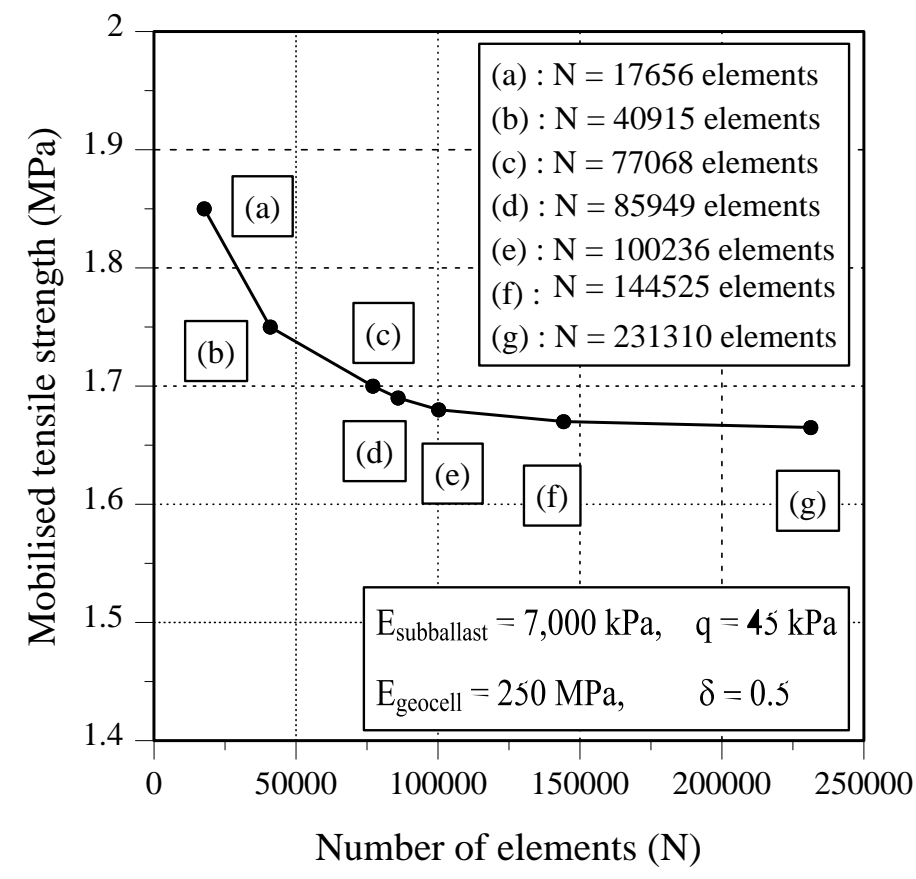

Figure 7. Mobilised tensile strength predicted by FEM model with different number of elements $(N)$. 
Pull-out force

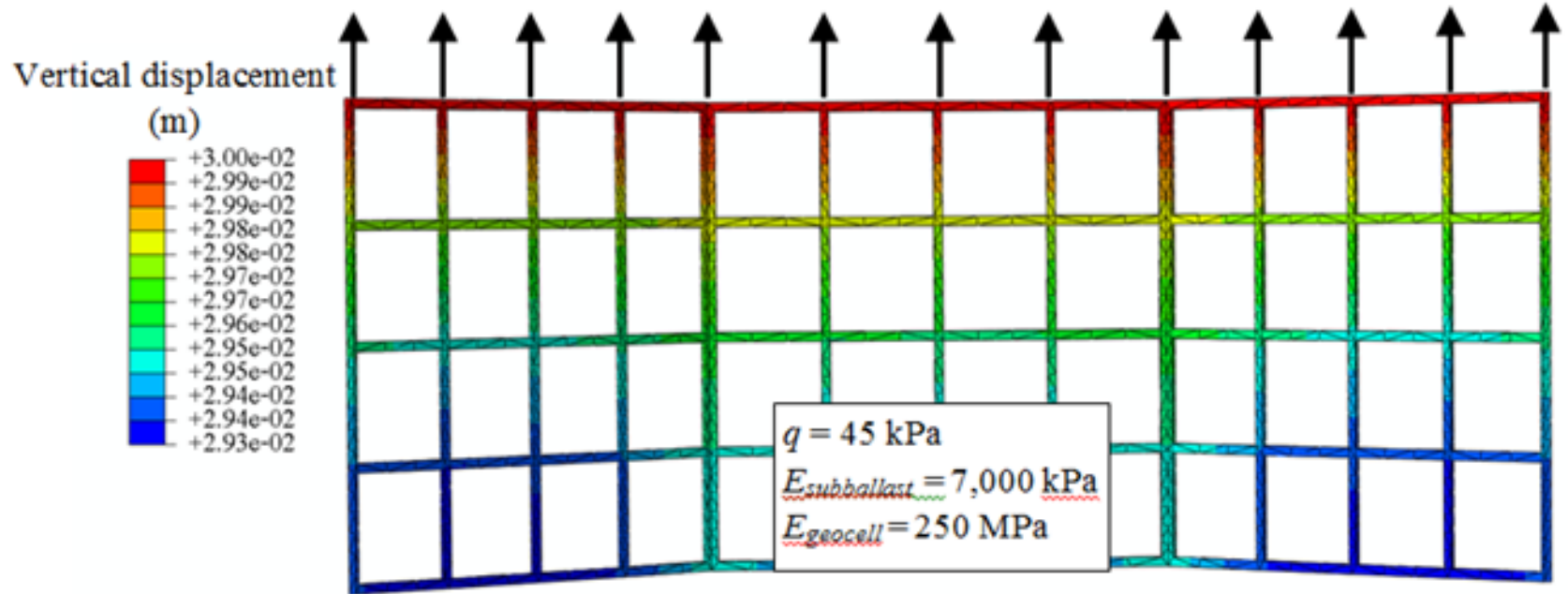

(a)

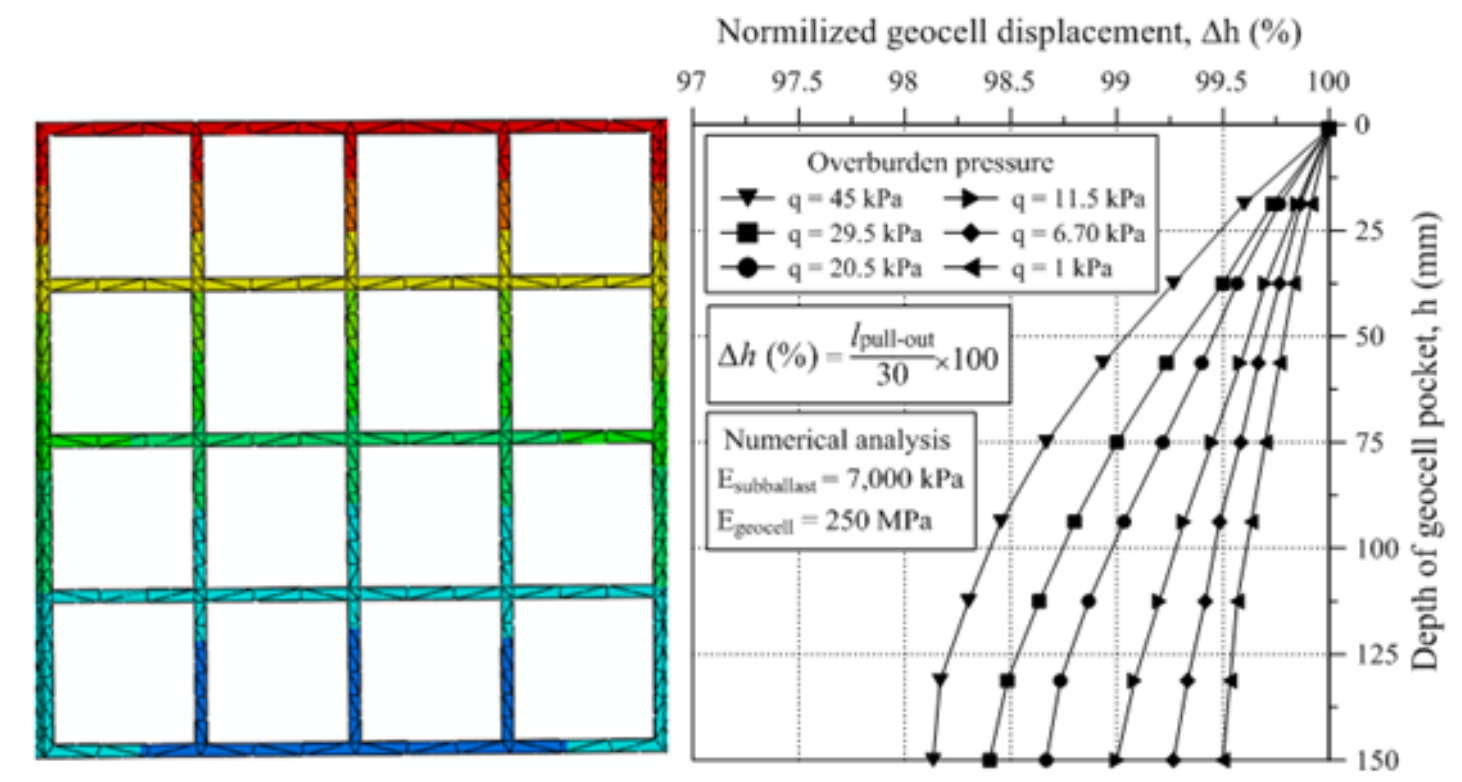

(b)

Figure 8. (a) Typical geocell displacement during pullout force, and (b) variation of axial displacement of longitudinal ribs at different depth of geocell pocket. 


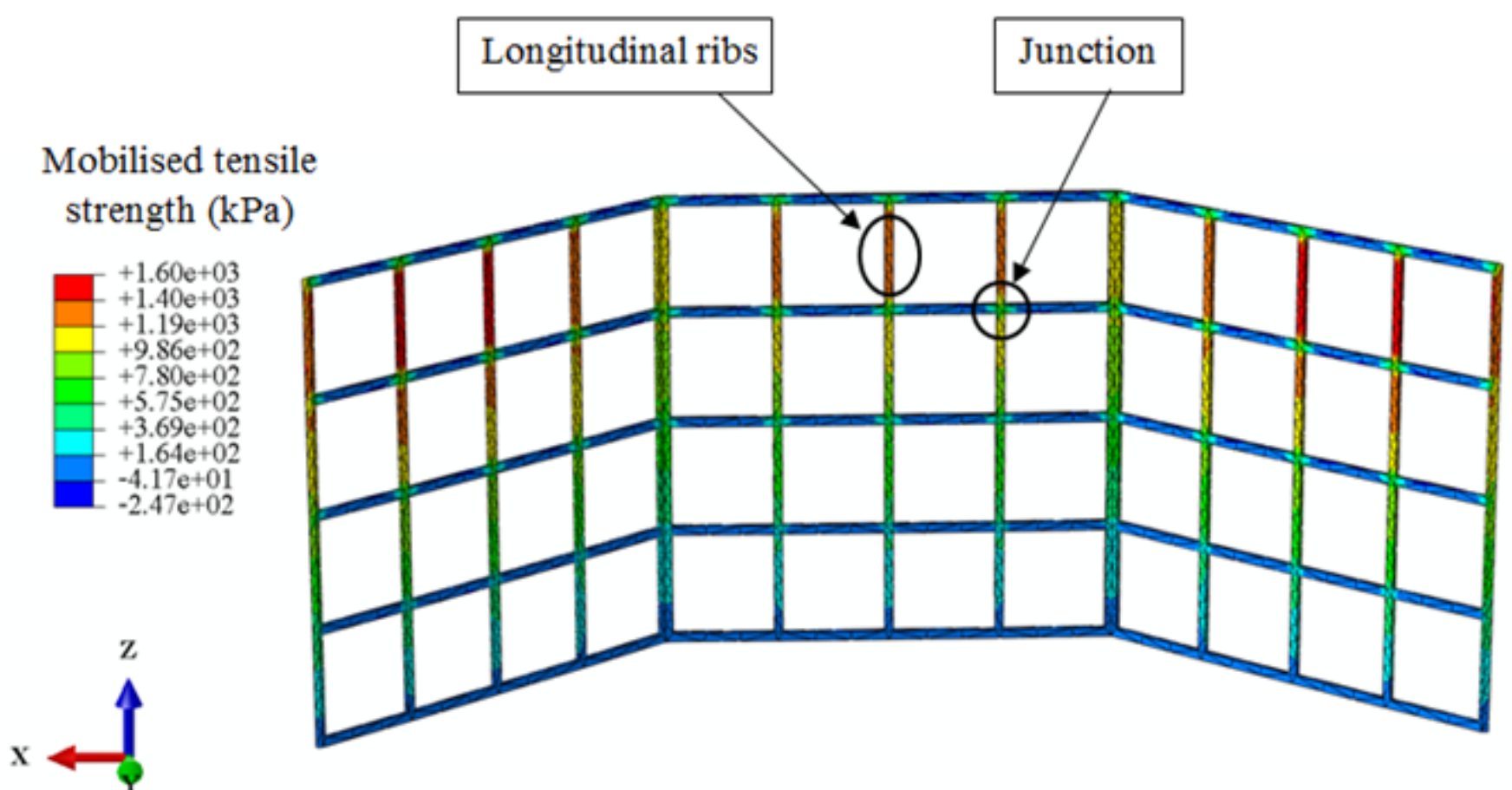

(a)

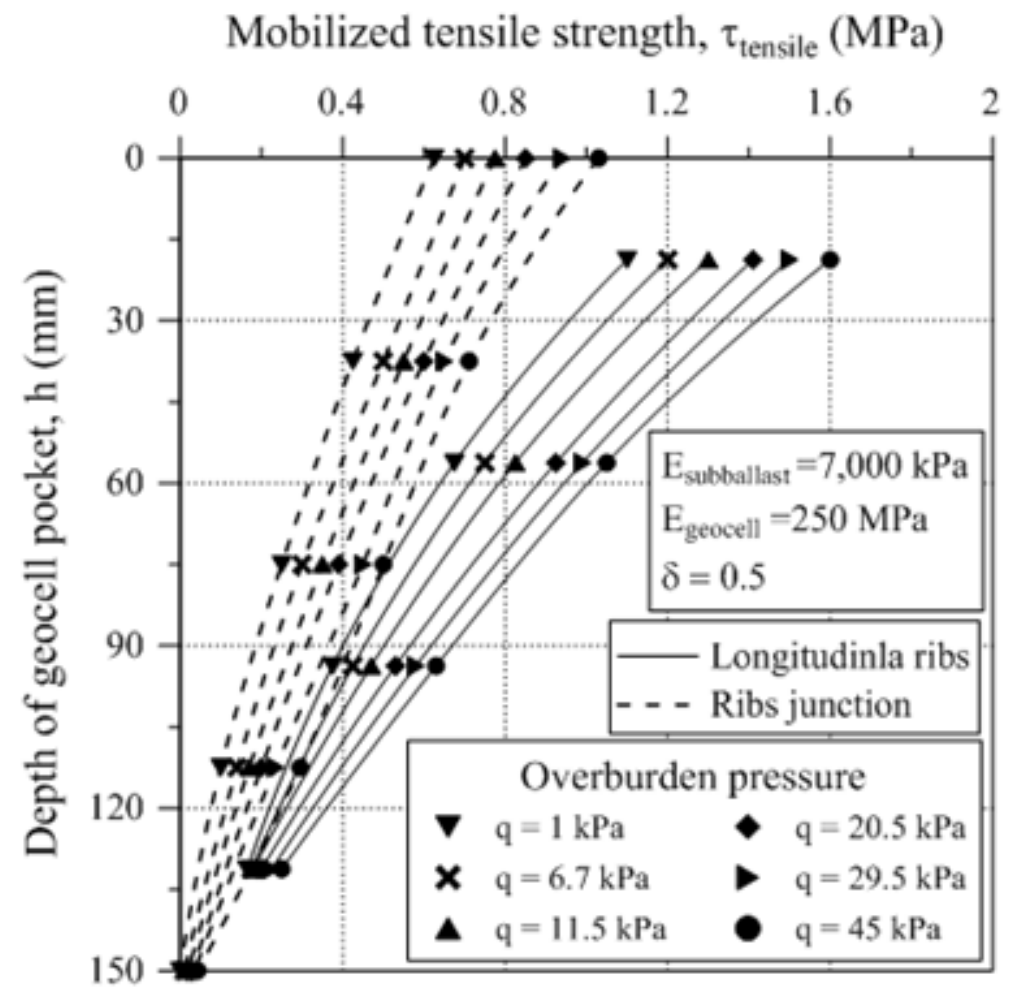

(b)

Figure 9. Typical mobilised tensile stregnth in (a) geocell formed by geogeid GG2 and (b) at different depths of geocell pocket. 


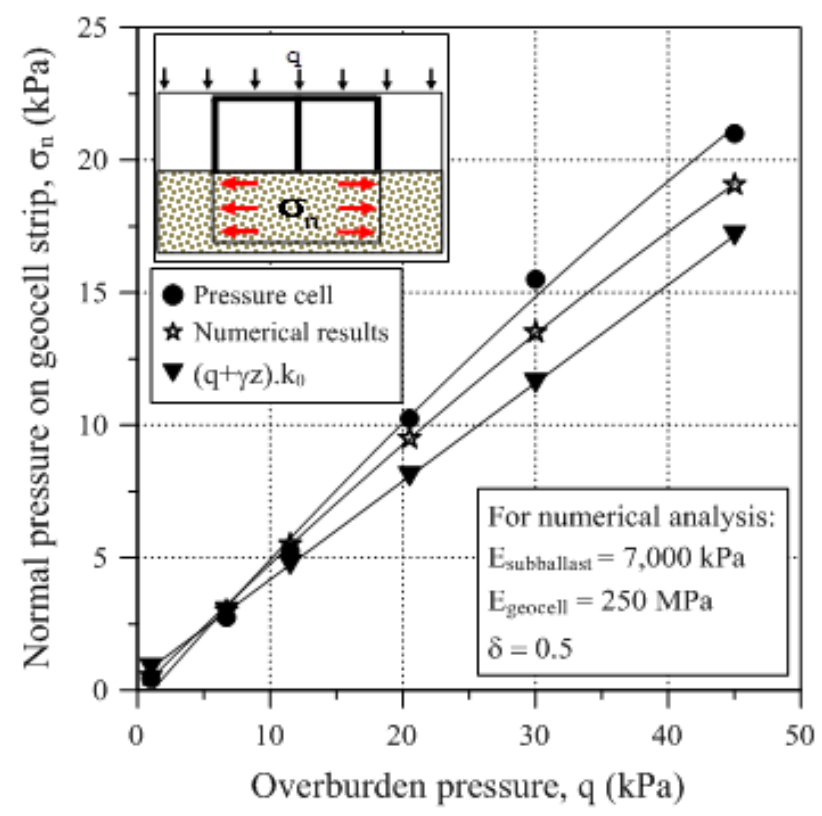

(a)

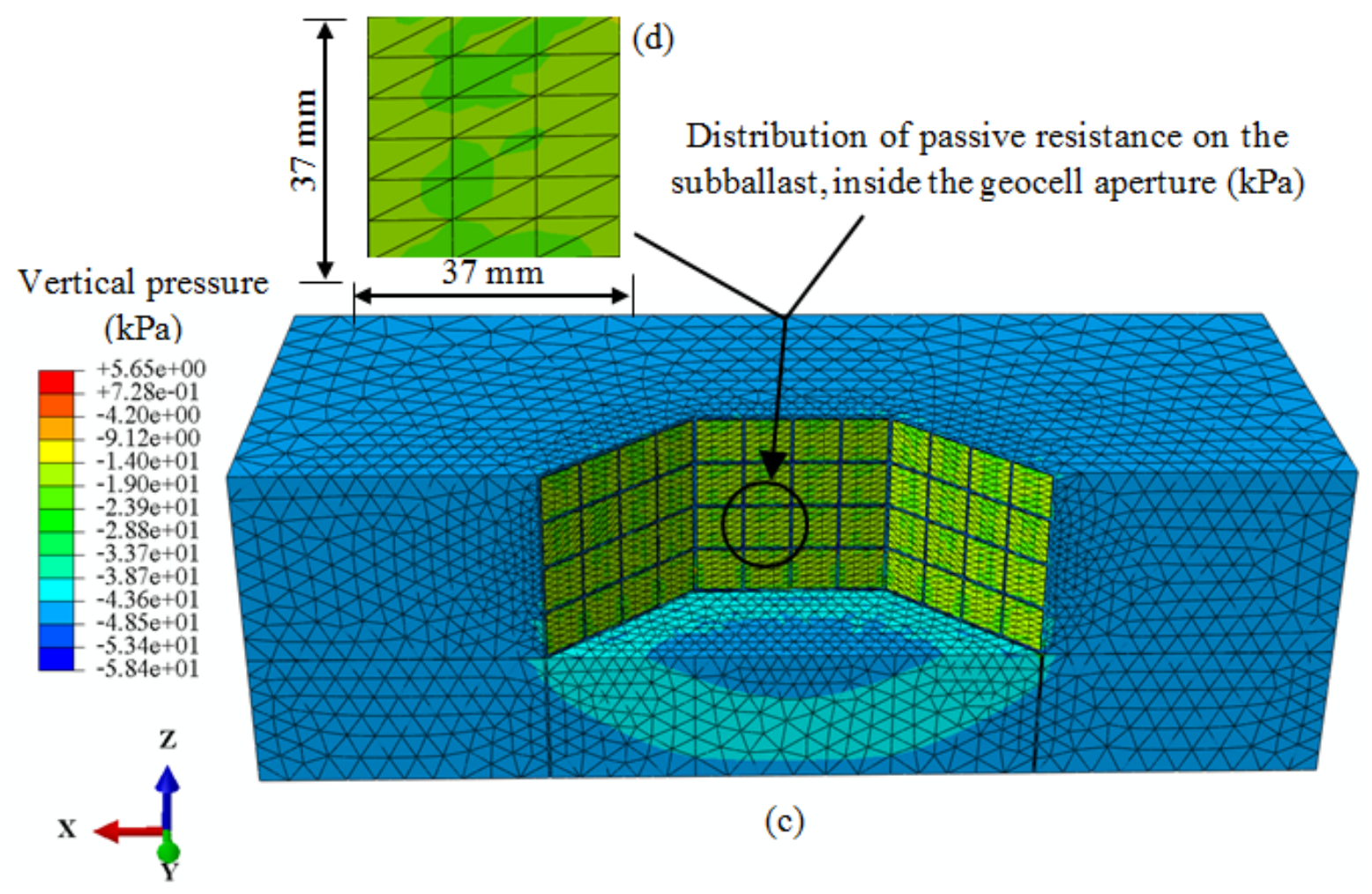

Figure 10. (a) normal stress developed over geocell strips; (b) passive resistance at different overburden pressures, (c) typical normal stress in the geocell-renforced subballast; and (d) passive resistacne in the soil trapped in the geocell apperture. 


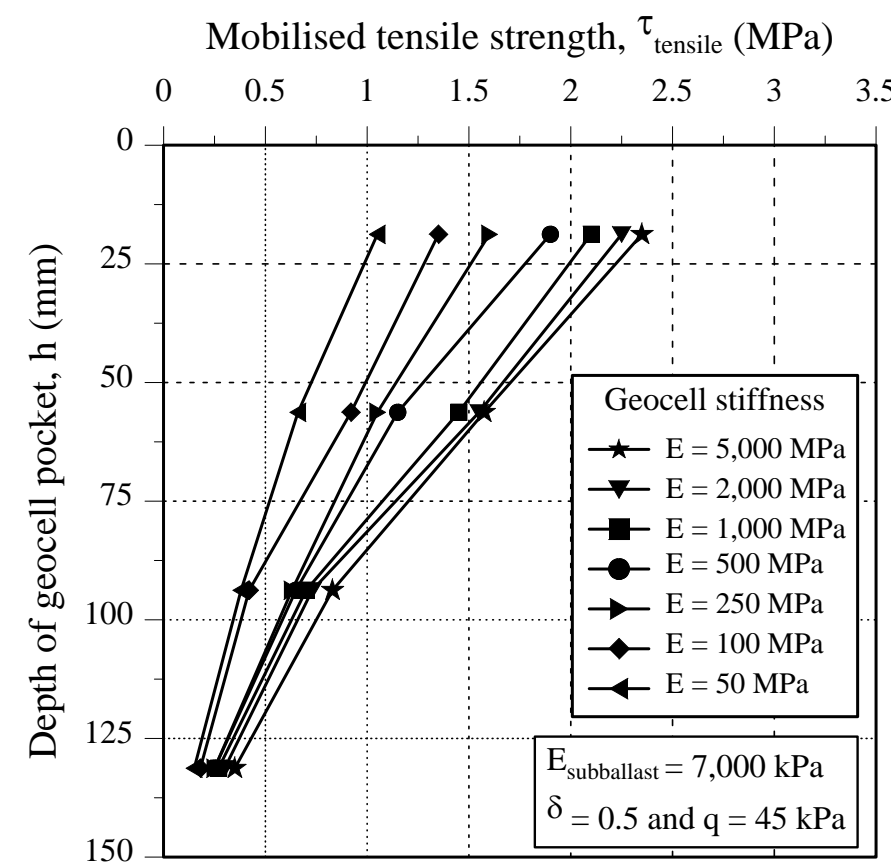

(a)

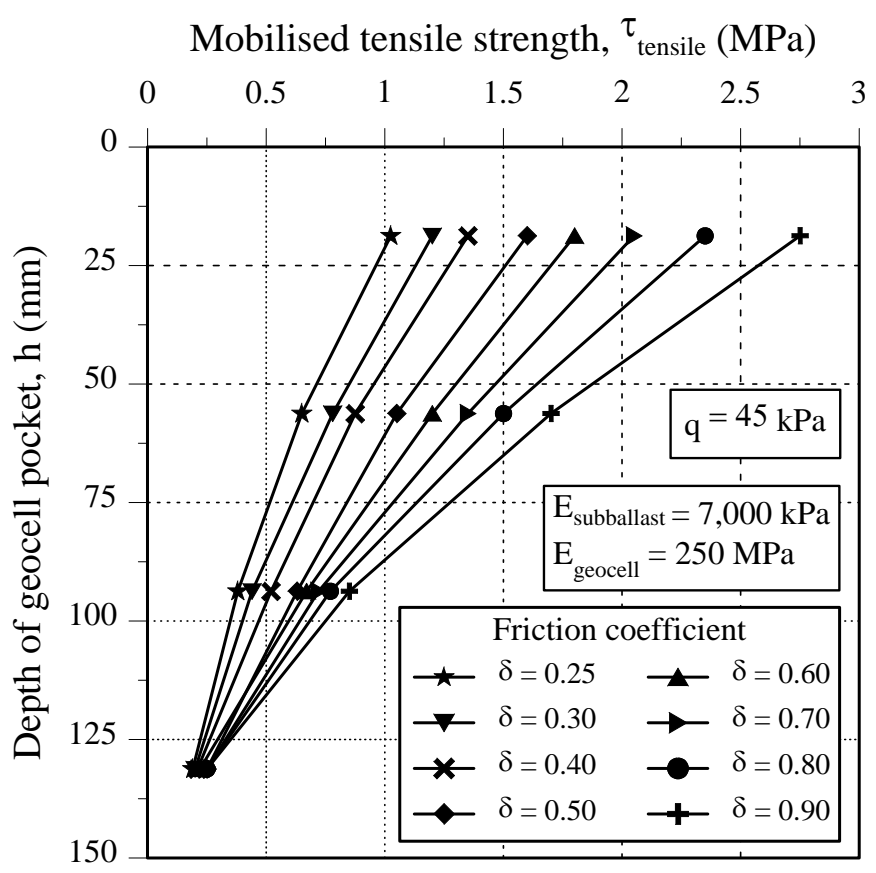

(b)

Figure 11. Variations of mobilised tensile strength: (a) varying geocell stiffnesses $\left(E_{\text {geocell }}\right)$; and (b) varying friction coefficient $(\delta)$. 


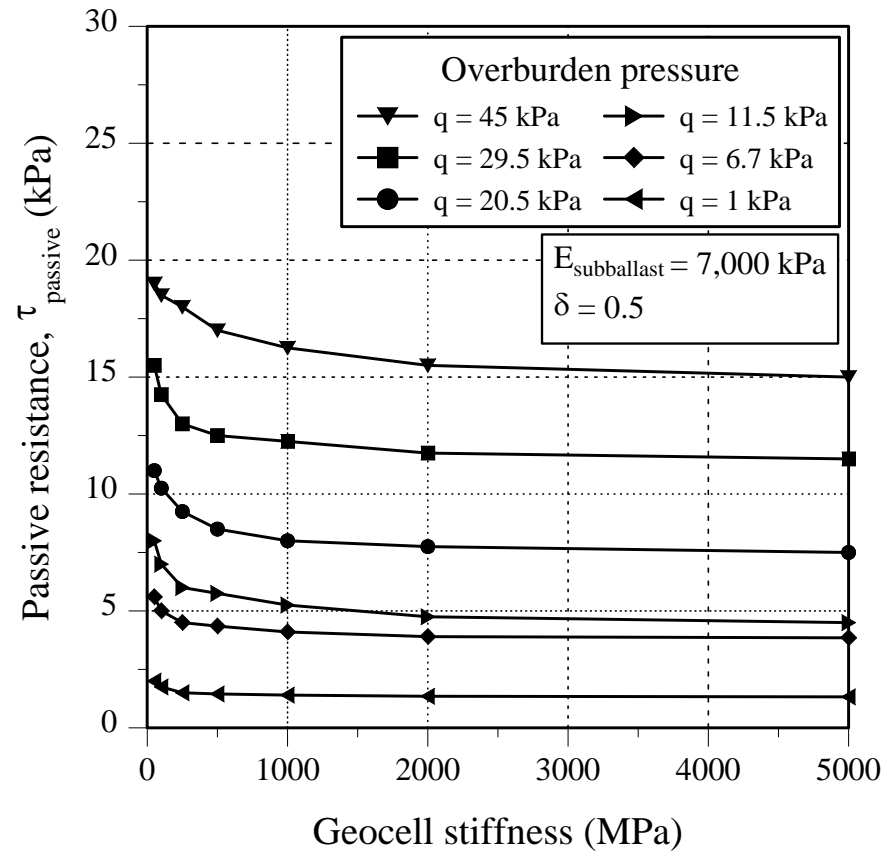

(a)

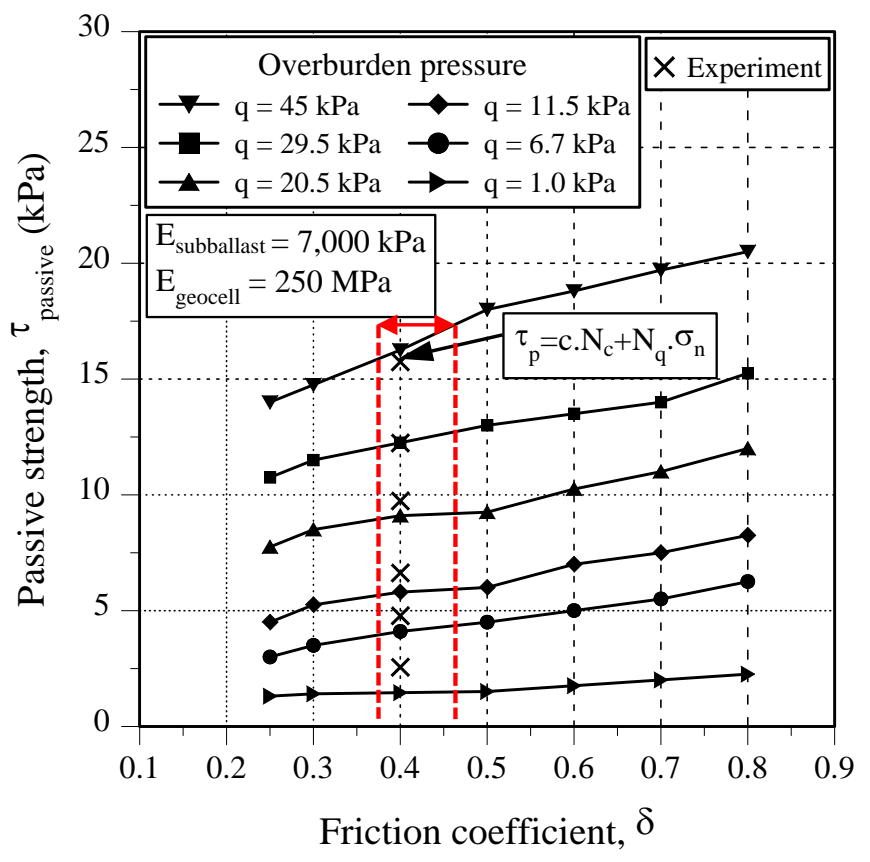

(b)

Figure 12. Variations of passive resistance: (a) varying geocell stiffnesses ( $\left.E_{\text {geocell }}\right)$; and (b) varying friction coefficient $(\delta)$. 